\title{
External Balance Sheets as \\ Countercyclical Crisis Buffers
}

\author{
by \\ Joseph P. Joyce* \\ Department of Economics \\ Wellesley College \\ Wellesley, MA 02481 \\ jjoyce@wellesley.edu
}

July 2015

\begin{abstract}
The external balance sheets of many emerging market countries are distinguished by their holdings of assets primarily in the form of foreign debt and foreign exchange reserves, while their liabilities are predominantly equity, either FDI or portfolio. In this paper we investigate the claim that this composition served as a buffer for the emerging markets during the global financial crisis of 2008-09. We use data from a sample of 67 emerging market and advanced economies, and several indicators of the crisis are utilized: GDP growth rates in 2008-09, the occurrence of bank crises and the use of IMF credit. Our results show that those countries that issued FDI liabilities had higher growth rates, fewer bank crises and were less likely to borrow from the IMF. FDI assets, on the other hand, were linked to steeper contractions in GDP and more participation in IMF programs. Portfolio assets and liabilities had similar impacts, but their coefficients were less significant. Countries with debt liabilities, on the other hand, had more bank crises and were more likely to use IMF credit. We conclude that the "long debt, short equity" strategy of emerging markets did mitigate the effects of the global financial crisis.
\end{abstract}

* This paper benefitted from the outstanding assistance of Yiran Cheng and Evelyn TaylorMcGregor. 


\section{External Balance Sheets as \\ Countercyclical Crisis Buffers}

\section{Introduction}

While the global financial crisis (GFC) of 2007-09 was truly an international phenomenon, some countries were more severely affected than other. The decline was steepest in the high-income countries, where GDP contracted in 2009 by $3.5 \%$. The emerging market and developing economies also recorded declines in growth rates, but the differences between their rates and those of the advanced economies rose during the crisis (see Figure 1). The relatively stronger performance of the emerging markets and developing economies has been attributed to several factors, including improved macroeconomic policies, stronger external positions before the crisis, more regulated financial sectors and a rapid response by the IMF. ${ }^{1}$ In this paper we investigate whether the composition of the external balance sheets of emerging market nations also mitigated the effects of the global downturn on their economies.

After the financial crises that occurred in emerging markets during the late 1990s and early 2000s, many of these nations altered the compositions of their external balance sheets. Countries that once had borrowed external funds primarily through debt in the form of bonds or bank loans turned to equity, either foreign direct investment (FDI) or portfolio equity, for sources of finance. As a result, their equity liabilities grew steadily, both in terms of magnitude and relative to their debt liabilities. Their assets, on the other hand, have largely consisted of the foreign exchange reserves of their central banks, held in the form of U.S. Treasury bonds, and other debt holdings. This profile is known as "long debt, short equity," and differs from the "long equity, short debt" composition of most advanced economies that hold equity and issue debt.

Lane (2013) has claimed that the structure of the emerging markets' external balance sheets served as a buffer against the GFC, while the contrasting profile of many advanced 
economies' assets and liabilities heightened their vulnerability. Similarly, Gourinchas, Rey and Govillot (2010) have maintained that the U.S. provided "insurance" to other countries against the effect of the crisis through its holdings of their equities. The fall in equity valuations combined with depreciations against the dollar lowered the value of the liabilities of the emerging market nations while the value of their foreign-currency denominated assets increased, thus raising their net international investment positions (NIIP). Similarly, the payments on their equity liabilities fell, while the earnings they received on their holdings of debt largely continued to be paid, which improved their net investment income balance. The advanced economies that were net holders of equity, on the other hand, suffered deteriorations in their external positions and net income balances. They were also subject to capital flight and financial volatility, which was much less of a threat for the emerging markets that had issued FDI.

This paper tests whether the composition of external assets and liabilities affected the impact of the GFC on emerging markets and advanced economies. We specifically look at the net holdings and gross stocks of equity and debt assets and liabilities. We investigate their effect on GDP growth rates during the crisis, the incidence of bank crises and participation in IMF programs. While other papers have explored the causes and extent of the GFC (see literature review below), ours concentrates on how the external holdings of equity and debt affected the response of countries to the GFC.

To preview our results, we find that countries with FDI liabilities recorded smaller declines in GDP growth, experienced fewer bank crises and were less likely to enter IMF programs. Holdings of FDI assets were associated with lower growth rates and more frequent use of IMF credit. Portfolio assets and liabilities had similar impacts but their coefficients are less significant. External debt liabilities, on the other hand, were associated with a greater incidence 
of bank crises and more use of IMF credit. Our results, therefore, demonstrate that the "long debt, short equity" strategy of many emerging markets did act as a countercyclical stabilizer to mitigate the effects of the global financial crisis. FDI liabilities in particular serve as a risksharing mechanism, which can provide the basis of a "pecking order" of international capital flows.

The next section presents a selective review of the relevant literature. Section 3 describes the empirical model and data. Section 4 contains our main results for the investigation of a linkage between the severity of the crisis and the composition of the external balance sheet. In section 5 we examine the robustness of our results. Section 6 offers a pecking order for the different forms of capital flows based on our results, which we compare with other rankings that have been advanced. The last section offers our conclusions and proposes extensions of the research.

\section{Literature Review}

Figure 2 provides a stylized version of a country's external balance sheet, which records the foreign assets owned by domestic residents and the domestic liabilities owned by foreigners. The net position determines a country's NIIP as a creditor or debtor. The foreign assets are denominated in the foreign currencies, while domestic equity is denominated in the domestic currency. Domestic debt held outside a country may be denominated in the domestic or a foreign currency. $^{2}$

Lane and Milesi-Ferretti $(2001,2007)$ in a series of seminal papers provided data and analysis on the external assets and liabilities of a wide range of countries. They pointed out that international financial integration had advanced much further in the advanced economies than in 
the emerging markets. Lane and Milesi-Ferretti (2007) and Kose and Prasad (2010) also noted the increase over time by emerging market countries in the use of equity liabilities. The advanced economies that hold these liabilities have themselves issued debt liabilities, which in turn are held by the emerging markets. In the empirical literature, Faria et al. (2007), Faria and Mauro (2009) and Vermeulen and de Haan (2014) attribute the rise in the issuance of equity liabilities by emerging markets to improvements in institutional quality and/or financial development in these countries. ${ }^{3}$

The external balance sheet can affect a country's performance during a crisis through several transmission mechanisms. The first is a wealth effect exerted through a country's NIIP. Gourinchas and Rey (2007a, 2007b, 2014), who examined the role of external balance sheets in preserving the intertemporal budget constraint, focused on the role of valuation changes, which are driven by fluctuations in the market values of assets and liabilities as well as exchange rate movements. A decline in the value of equity, for example, will lower the NIIP of those nations that are "long" equity, while raising it for those that are "short" equity. A depreciation of the exchange rate has mixed effects: on the one hand, it increases the value of a country's foreign assets while lowering the value of liabilities denominated in the domestic currency. But it also raises the value of any foreign-held debt that is denominated in a foreign currency.

These changes in the NIIPs can exert wealth effects on expenditures. Kubelec, Orskaug and Tanaka (2007) analyzed the external balance sheets of the United Kingdom, the U.S. and Canada, and described how changes in these would impact economic activity within the countries. Cavallo et al. (2005), using data from 24 crises in the 1990 s, reported that balance sheet effects due to exchange rate overshooting led to large contractions in output. ${ }^{4}$ 
The second channel of transmission between the composition of the balance sheet and economic performance takes place through the flow of net investment income. Dividend payments on equity investment are state-contingent, while debt payments are contractual in nature. Consequently, in normal times equity payments incorporate an equity "premium," and equity payments exceed those on debt. But during a crisis, the equity payments are cut as profits fall, while debt payments continue, except in the extreme case of a default. Net income payments for China, for example, are usually negative despite the country's NIIP status as a creditor because the payments made on foreign-held FDI exceeds the interest received on U.S. Treasury and other securities. Ma and McCauley (2014) pointed out, however, that in 2008 China's net income payments turned positive due to the reduction in income outflows while the country continued to receive a return, albeit a small one, on its holdings of U.S. Treasury debt. Lane (2001), Balli, Basher and Balli (2011) and Bracke and Schmitz (2011) examined whether investment income flows and capital gains can smooth income.

Third, the structure of the external balance sheet influences the degree of volatility in financial flows before and during crises. The size of the gross stocks of assets and liabilities may be as important as a country's NIIP. Changes in these stocks can overwhelm financial markets and institutions, and exacerbate a crisis. In the case of a "sudden stop," there is a severe drop in inflows and the reversal of a current account deficit, which is often accompanied by a recession.

Several studies have compared the relative stability of equity and debt flows during crises. Levchenko and Mauro (2007), for example, found that FDI flows were stable during periods of sudden stops, while portfolio equity played a limited role in the proliferation of these crises. Portfolio debt, on the other hand, and bank flows were more likely to be reversed. Similarly, Sula and Willett (2009) investigated the behavior of capital flows during currency 
crises, and reported that FDI was the most stable, while loans were as likely to be reversible as portfolio flows.

The role of external assets and liabilities in propagating financial crises has been extensively studied. The debt crisis of the 1980s, for example, was due in part to the bank debt that developing economies had accumulated in the previous decade. Rodrik and Velasco (2000) showed that short-term bank debt contributed to the occurrence of capital flow crises during the period of 1988-98.

Pistelli, Selaive and Valdés (2008) investigated how the composition of external assets and liabilities affected the occurrence of current account reversals, sudden stops and currency crises. Portfolio equity liabilities were associated with a higher occurrence of current account reversals, while FDI liabilities had the opposite effect. They also found that FDI assets made sudden stops more likely, but portfolio equity assets and FDI liabilities lowered the probability of their occurrence. Catão and Milesi-Ferretti (2014) noted that that an increase in net foreign assets lowered the probability of the occurrence of external crises. They reported that debt liabilities were a significant determinant of these crises, while FDI had the opposite effect, i.e., an increase in FDI liabilities lowered the risk of a crisis. Similarly, Frankel and Wei (2005) found that the share of FDI and portfolio equity in gross external liabilities decreased the change of a currency crisis.

There are also studies that explicitly compare the effect of equity and debt flows. Furceri, Guichard and Rusticelli (2012) found that large capital inflows driven by debt increase the probability of banking, currency and balance-of-payment crises, while inflows that are driven by FDI or portfolio equity have a negligible effect. Forbes and Warnock (2012) also found that 
episodes of extreme capital movements are associated with debt flows, whereas equity flows are not.

Several recent papers have dealt with the impact of external assets and liabilities in the GFC. ${ }^{5}$ As stated above, Lane (2013) suggested that the "long debt, short equity" external profile of the emerging markets "...provided valuable insulation against the crisis. In contrast, the "long equity, short debt" profile of many advanced economies was a risky profile in the face of declining equity markets and disruption in credit markets." Gourinchas, Rey and Truempler (2012) examined the wealth transfers that took place via changes in external positions during the crisis to determine which countries benefitted and which lost.

Al-Saffar, Ridinger and Whitaker (2013) also looked at external balance sheets during the GFC, and found that external debt liabilities contributed to the deviation of GDP in 2009 from its 1997-2007 trend. They did not find evidence of a linkage from net equity holdings to the slowdown in growth, but did not decompose equity into its FDI and portfolio components. Balli, Basher and Balli (2013) investigated income factor flows in advanced economies during the crisis, and reported that debt provided better risk sharing than equity.

Llaudes, Salman and Chivakul (2010) examined the record of the crisis in emerging market economies. They found that the impact of the crisis was more pronounced in those countries with weaker fundamentals and greater financial and trade linkages. The financial variables included foreign bank claims on the countries. Berkmen et al. (2012) also investigated the GFC and the emerging market countries, and reported that financial channels were the main channel of transmission, with leverage and short-term debt contributing to lower growth. Didier, Hevia and Schmukler (2012) found that more trade and financial openness, current account 
deficits, and higher growth rates of credit contributed to collapses in GDP growth in emerging markets.

Our research, therefore, draws from several strands of the literature, including analyses of external capital structures, external adjustment, and the record of the GFC. We build upon this work to examine whether the composition of external balance sheets affected economic performance during the GFC. We use different measures of the severity of the crisis, and evaluate the impact of net holdings of equity and debt as well as gross stocks. We leave for future work an investigation of the determinants of the components of the balance sheets.

\section{Data}

We obtained data for 67 countries, which included 44 emerging market economies and 23 advanced economies. ${ }^{6}$ We did not include small financial centers with oversized financial holdings (Hong Kong, Iceland, Ireland, Luxembourg, Singapore), countries where oil exports were the dominant source of economic activity or those with populations below one million. The countries included in the sample are listed in the Appendix.

The data on external assets and liabilities were taken from the latest version of the "External Wealth of Nations" dataset, which was constructed by Lane and Milesi-Ferretti (2007). ${ }^{7}$ We use the NIIP scaled by GDP (NIIP/Y), as well as the sum of external assets and liabilities scaled by GDP as a measure of de facto financial openness (Fin Open/Y). We also use a country's net equity position scaled by GDP (Net Eq/Y) and its components, the net FDI balance (Net FDI/Y) and the net position in portfolio equity (Net Prt/Y), net debt (Net Dbt/Y), and the central bank's foreign exchange assets scaled by GDP (For Res/Y). In addition we use measures of the gross stocks of assets and liabilities, all scaled by GDP: FDI assets (FDI Ast/Y) 
and liabilities (FDI Lbt/Y), portfolio assets (Prt Ast/Y) and liabilities (Prt Lbt/Y), and debt assets (Dbt Asset/Y) and liabilities (Dbt Lbt/Y).

Figure 3 shows the ratio of equity/debt liabilities for the countries in our sample in 2007. It confirms that most emerging market economics (the countries with red bars) had ratios above $100 \%$, although there are outliers such as Lithuania and Latvia, which borrowed extensively from West European banks. Similarly, most advanced economies (blue bars) had issued more debt than equity, although again there are exceptions, such as Canada.

Our crisis indicators include GDP growth rates, participation in an IMF program and banking crises. ${ }^{8}$ We provide more detail for each crisis variable as well as the control variables used in the empirical analysis in the following sections of results. A list of all the variables and their data sources and descriptive statistics appears in the Appendix.

\section{Results}

\subsection{Growth}

The decline in economic activity during 2008 and 2009 was used by Lane and MilesiFerretti (2011) in their analysis of the cross-country severity of the crisis, and in several subsequent similar studies. We follow them in our specification of the dependent variable, the average real growth rate of GDP over the two years, and the choice of control variables. The range of values of average GDP growth during the two crisis years is shown in Figure 4, which shows that most emerging market countries had higher growth rates than most advanced economies.

The control variables for the growth regressions include the current account as a percentage of GDP (Cur Act/Y); the change in domestic credit during the period of 2004-2007 as 
a percentage of GDP ( $\triangle \mathrm{Dom} \mathrm{Cr} / \mathrm{Y})$; the logarithm of GDP per capita in dollars (Y/Pop); and trade openness as measured by exports and imports as a percentage of GDP (Trad Open/Y). The current account data were obtained from the "External Wealth of Nations," while the data for the other control variables were taken from World Development Indicators. We added the external balance sheet variables listed above. We used the 2007 values of all these variables to avoid simultaneity.

Our results are reported in Table 1. The results for the control variables are quite similar to those of Lane and Milesi-Ferretti (2011). The countries with better growth records during the crisis were those with higher current account balances, smaller growth in domestic credit in the period leading up to the crisis and lower GDP per capita. Trade openness and financial openness were not significant, with the possible exception of the results in one of the subsequent equations where their coefficients are negative and positive, respectively. The adjusted $\mathrm{R}^{2} \mathrm{~s}$ range from 0.38-0.46, and these are also similar to those reported by Lane and Milesi-Ferretti (2011).

Turning to the external balance sheet variables, a country's net international investment position scaled by GDP appears in the first equation with a negative coefficient that is significant at the $5 \%$ level. A higher net position in the period before the crisis led to lower growth during the crisis. In order to ascertain which assets and liabilities drive this result, in equation 1.2 we replace the NIIP with its components: net equity/GDP, net debt/GDP and foreign exchange reserves also scaled by GDP. Net equity appears with a highly significant negative coefficient, while net debt and foreign reserves are not significant. ${ }^{9}$ In equation 1.3 , we replace net equity with its components, net FDI and net portfolio equity, and drop the other two variables from the previous estimation. The coefficient of the net FDI variable is negative and significant at the $1 \%$ level, whereas the coefficient of the net portfolio variable is negative but not significant. 
We then replace the net equity and net debt positions with their components: FDI assets and liabilities in equation 1.4, portfolio assets and liabilities in equation 1.5 , and debt assets and liabilities in equation 1.6. Only the FDI variables appear to be significant: FDI assets with a negative coefficient and FDI liabilities with a positive coefficient, both significant at the 5\% level. The two findings suggest that the countries that hosted foreign partners did better during the crisis than did their partners' home countries.

Figure 5 plots the countries' Net FDI positions in 2007 against their average growth in 2008-09. The advanced economies are concentrated in the right-hand and lower quadrant and the emerging markets appear mainly in the left-hand and upper quadrant. Given their positions, it might be argued that the net FDI variable is a proxy for something else that distinguishes emerging market countries from advanced nations. Our GDP per capita variable should control for that, but we also estimated the equations using only data from the emerging market countries, and Table 2 reports those results.

The results are consistent with those of the previous table, and the adjusted $\mathrm{R}^{2} \mathrm{~s}$ are higher. The current account is not always significant in these regressions, but the negative impact of domestic credit and income per capita are. The net equity and net FDI variables appear with negative coefficients that are significant at the 5\% level. The FDI assets coefficient has a negative coefficient that is significant at the 5\% level, while the positive impact of FDI liabilities is significant at the $10 \%$ level. The results indicate that within this group of emerging market countries, there was a range of external balance sheet positions and responses to the crisis that are consistent with the hypothesis that countries with a "short equity" position did better than those that were not. 
As a further test of robustness, we respecified our dependent variable to be the difference between average growth in 2008-09 and the growth rate projected by the IMF in its publication, World Economic Outlook, in the October issue of the previous year. ${ }^{10}$ Those results appear in Table 3, and are generally consistent with those of the previous two tables, although the adjusted $\mathrm{R}^{2} \mathrm{~s}$ are lower. The negative sign of the change in domestic credit is strongly significant, as is the negative sign of trade openness, but the coefficient of the current account is not. Increases in net equities and net FDI are associated with slower growth in 2008-09 at the 5\% level of significance. The positive coefficient of FDI liabilities, which is significant at the $10 \%$ level, demonstrates that these liabilities provided a buffer against the worst effects of the shock. Additional tests of robustness are reported in Section 5.

Our results for the positive role of FDI liabilities in moderating the effect of external shocks are consistent with evidence from microeconomic studies of the GFC. ${ }^{11}$ Tong and Wei (2011) used firm-level data to analyze the impact of capital flows on stock prices during the GFC. They reported the 2008-09 "credit crunch" was more severe for emerging economies with a higher pre-crisis exposure to foreign portfolio investment and foreign loans, but FDI flows alleviated the impact. Similarly, Alfaro and Chen (2012) examined the response of firms to the crisis and fund that the sales of multinational subsidiaries fared better than those of domestic firms. They attributed the difference in performance to production and financial linkages between domestic subsidiaries and parent firms.

Our results confirm that the composition of external assets and liabilities affected the response of countries to the GFC. FDI liabilities appear to be particularly important in buffering nations from declines in growth due to foreign shocks, while FDI assets had the opposite effect. The results are consistent with other analyses of the linkages among nations during the GFC. 
First, changes in the values of investments that had been financed by foreign funds contributed to the transfer of wealth documented by Gourinchas, Rey and Truempler (2012). Since most countries report only the book value of their FDI positions, they used equity price index changes to estimate the changes in market values of foreign investments. They reported that "...most countries long equity or direct investment faced losses on their net positions, as risky assets took some of the sharpest valuation falls in the crisis." The U.S., for example, had an overall valuation loss of $\$ 2,069$ billion when direct investment is measured at market value.

The counterparts to these losses were the gains in the NIIPs of those countries that had issued FDI liabilities. Lane (2013) pointed out these improvements were a "stabilizing force," which differed from the usual pattern observed in previous emerging market crises when debt liabilities denominated in a foreign currency were more common on the balance sheets of those countries. Similarly, Ceballos et al. (2013) pointed out that the emerging markets were willing to allow their currencies to depreciate during the GFC since the decline in currency values contributed to the fall in value of their liabilities that were denominated in the local currency. The opposite changes occurred in the U.S., which was a net holder of equities and recorded a currency appreciation during the GFC.

In addition, FDI flows were less volatile than other forms of capital flows during the crisis. Wei (2011) examined capital flows to 24 emerging economies from 1990 to 2009 . He found that that all the components of these flows rose in the years leading to the crisis and then were reversed. But the sharpest rise and fall were for international bank loans, while FDI flows were "comparatively stable." Globan (2012) also found that countries that relied on foreign loans rather than FDI in the pre-crisis period suffered larger capital flow reversals during the crisis. This stability benefitted those countries that had obtained external financing through FDI, while 
those that had borrowed through banks had to deal with the repercussions of the reversal of bank lending.

\subsection{Bank Crises}

Capital outflows have been linked to domestic bank crises, and to investigate whether this form of financial instability manifested itself during the GFC, we tested whether the composition of the balance sheet affected the probability of a bank crisis. We drew upon past work, including the papers cited above, in specifying our model. ${ }^{12}$ The dependent variable took the value of one if a systemic bank crisis was recorded in 2008 or 2009 in Laeven and Valencia's (2013) crisis database. ${ }^{13}$ There were 20 crises in our sample, and these are noted in the list of countries in the Appendix. The control variables include the change in domestic credit from 2004 to 2007, the logarithm of GDP per capita and financial openness. We also included the rate of real GDP growth $(\% \Delta \mathrm{Y})$ and inflation $(\% \Delta \mathrm{P})$ in 2007 . Since the dependent variable is binary, we used a probit estimation.

The results are presented in Table 4. All the control variables have the expected signs and are significant in at least some of the estimations, and the pseudo $\mathrm{R}^{2} \mathrm{~s}$ are relatively high. The growth of domestic credit and inflation have positive coefficients significant at the $5 \%$ or $10 \%$ level in all the equations. Per capita income and financial openness also contribute to the incidence of bank crises.

Countries with larger net holdings of equity were more likely to suffer a bank crisis. When we replace the net equity variable with the net FDI and net portfolio equity positions, the coefficient of the former is significant at the $10 \%$ level. We then test the significance of the various forms of liabilities. FDI liabilities have a negative coefficient that is significant at the 
$10 \%$ level, which explains the negative coefficient on net FDI. The coefficient of the debt liability variable has the opposite sign, also at the $10 \%$ level.

Countries that issued external debt to finance borrowing, therefore were more likely to subsequently experience a banking crisis, while the use of FDI liabilities had the opposite impact. Joyce (2011) examined systemic bank crises in a sample of emerging markets, and also found that foreign debt liabilities contributed to an increase in the incidence of bank crises, while FDI and portfolio equity liabilities had the opposite effect. Ahrend and Goujard (2014) confirmed that debt liabilities increase the occurrence of systemic banking crises.

\subsection{IMF Programs}

The IMF played an active role in responding the global crisis, and 11 of the countries in our sample entered IMF programs during the period of September 2008 through $2009 .{ }^{14}$ In this section we examine whether the participation by governments in IMF programs was affected by the composition of external balance sheets. To choose appropriate control variables, we drew upon previous studies of IMF lending. ${ }^{15}$ In addition to the current account, the change in domestic credit, GDP per capita, and real growth, we also used government consumption divided by GDP (Gov/Y) and a dummy variable for fixed exchange rate regimes (Fix). ${ }^{16}$ We again used lagged values. The dependent variable has the value of one for the countries with IMF programs, and we used a probit estimation.

The results of these estimations are reported in Table 5. The results for the control variables reflect those of earlier studies. Those countries that had current account surpluses in 2007 were less likely to go to the IMF in 2008-09. Higher inflation rates, on the other hand, were linked to higher probabilities of IMF lending. The negative coefficient on per capita income 
demonstrates that during this period the only advanced economy to enter an IMF program was Iceland, which is not in the sample.

Countries that were net holders of equity were more likely to enter a Fund program, and the same result appears for the net FDI variable at a higher significance level. When we separate out FDI assets and liabilities, the assets have a positive coefficient significant at the $5 \%$ level while the negative coefficient on the liabilities is significant at the $10 \%$ level. These results are consistent with those reported in Tables $1-3$ with GDP growth rates, which found that FDI liabilities raised growth rates while assets had the opposite effect.

The GFC, moreover, had repercussions that lasted past the date when global GDP began to recover. This was particularly true in Europe, where the GFC was followed by a debt crisis. We added two countries to our list of those with IMF programs: Greece, which entered its first Stand-By arrangement in May 2010; and Portugal, which agreed to an Extended Fund Facility in June 2011. We kept the 2007 values of the independent variables, and reestimated the equations with the added programs.

These results appear in Table 6. The significance for the GDP per capita variable falls now that the two advanced economies are included in the list of IMF program county countries, while inflation is less important. The net debt variable appears with a negative coefficient that is significant at the $5 \%$ level, as does our foreign reserve variable. Similarly, the significance of the coefficient of net FDI rises to 5\%, as do the positive coefficient of FDI assets and the negative coefficient of FDI liabilities. Moreover, the two debt variables are also significant at the $5 \%$ level, debt assets with a negative coefficient and debt liabilities with a positive sign.

The results demonstrate clearly the importance of the composition of the external balance sheet. Those countries that were long FDI and short debt were more likely to take an IMF loan 
than those that were long debt and short FDI. Moreover, central bank holdings of foreign exchange reserves lowered the probability of entering a Fund program. Emerging market nations had learned the lessons of the crises of the 1990s and early 2000s, and their response worked to their advantage when the new crisis stuck.

\section{Extensions and Robustness}

We extended our estimations and tested them for robustness in several ways.

First, we introduced the exchange rate regime variable, FIX, into the estimations for GDP growth in Tables $1-3$. We used the variable and interacted it with each of the gross assets and liability measures to see if the existence of a fixed exchange rate regime affected the impact of the external balance sheet components on the change in GDP. The significance of the FDI variables did not change. The fixed exchange rate variable, however, and the interactive terms were not significant in any of the estimations.

Next, we introduced regional dummies to see if these affected our results. We used variables for East Asia, countries in the Eurozone and those that pegged their currencies to the euro, Latin America, the Middle East and North Africa, and South Asia, with the specifications of Table 1. We also interacted the regional dummy with the balance sheet variables. In only one case, the Eurozone and those that pegged their currencies to the euro, was there evidence of a regional effect. The results appear in Table 7 . The interactive variables are those that begin with "E*". We omit the results for the control variables, which are quite similar to those in Table 1, and for the last equation, where there was no effect, to conserve space.

The interactive variable of the euro dummy and net FDI has a positive coefficient that is significant at the $10 \%$ level. Similarly, in the case of net FDI, the euro dummy has a positive 
coefficient that is significant at the $5 \%$ level. The positive coefficients and the size of the coefficients indicate that the negative effect of the equity variables is largely offset in the case of the Eurozone countries and those that peg to the euro. Finally, the interactive variables have a positive sign in the case of FDI assets and a negative sign in the case of FDI liabilities, opposite to the signs of those variables themselves and close in absolute value. The impact of FDI did not seem to be relevant in the response of these European countries to the GFC.

We also rescaled our balance sheet variables by total assets and total liabilities. We included equity assets and liabilities as a share of total assets and liabilities, respectively (Eq Ast/Ast, Eq Lbt/Lbt), and did the same for FDI (FDI Ast/Ast, FDI Lbt/Lbt), portfolio equity (Prt Ast/Ast, Prt Lbt/Lbt), and debt (Dbt Ast/Ast, Dbt Lbt/Lbt). We also included the ratios of equity to debt assets (Eq Ast/Dbt Ast) and liabilities (Eq Lbt/Dbt Lbt), and the ratios of FDI to debt (FDI Ast/Dbt Ast, FDI Lbt/Dbt Lbt).

The results are sensitive to the inclusion of the income per capita variable in the regressions. As Figure 3 shows, the relative amounts of equity and debt usually depend on whether a country is an advanced or emerging market economy. Regressions of the composition of the balance sheet also show this. For example, regressions of the equity assets/liabilities as a share of all assets/liabilities on the logarithm of income per capita yield the following results (standard errors in parentheses):

$$
\begin{aligned}
& (\text { Eq Ast } / \text { Ast })=-146.23 * * *+17.42 * * *(Y / P o p) \\
& \text { (26.21) } \\
& \text { (2.67) } \\
& \text { adjusted } \mathrm{R}^{2}=0.39 \\
& (\text { Eq Lbt/Lbt })=125.70^{* * *}-8.07 * *(Y / P o p) \\
& \text { adjusted } \mathrm{R}^{2}=0.11
\end{aligned}
$$

Therefore, we report the results in Table 8 without the income per capita variable. These results are consistent with those reported in Table 1. All the equity assets, including both FDI 
and portfolio, lower economic growth rates, while equity and FDI liabilities raise it. There is no significant impact linked to debt assets or liabilities. The importance of the composition of the balance sheet is robust to this alternative specification.

Finally, we tried utilized another estimation method for Tables $4-6$, replacing the probit estimates with logit. There was no change in the levels of significance of the balance sheet variables. These results, which are available from the author, are consistent with those that we report.

\section{International Pecking Orders}

Our results can be used to devise a "pecking order" of the different forms of foreign capital by how well they buffer a country during a crisis. FDI ranks first as a crisis buffer, followed by portfolio equity, which had similar impacts but were generally insignificant, and then debt, which reinforced the effects of the crisis. We can compare this pecking order with those advanced by others (see Figure 6).

The original pecking order theory was advanced by Myers and Majluf (1984), and is based on an asymmetry of information about a firm's conditions. Managers know more about a firm's operations than do potential lenders, who therefore undervalue new equity offerings. The managers choose to finance investment first with retained earnings as these funds are cheaper than external finance, and then issue debt that is acceptable to lenders because of its contractual obligations. When the cost of debt begins to rise, they issue equity.

Razin, Sadka and Yuen (1998) devised a ranking for international capital flows, and reasoned that the relevant asymmetry of information is between domestic and foreign investors. They presented an analysis of how host governments should tax these forms of finance, and also 
ranked them in terms of public welfare. FDI, which avoids much of the informational asymmetries, is first, followed by portfolio debt and then portfolio equity.

Reisen and Soto (2001) also compared the properties of capital inflows in order to establish a pecking order based on their benefits and risks for capital-importing nations. They estimated the impact on growth of different forms of capital flows and used the results to determine which inflows most augmented growth. They found that the largest positive impact came from portfolio equity flows, followed by FDI. Bank lending, on the other had, was negatively associated with growth, except when local banks were sufficiently capitalized, while bond flows had no significant impact.

Daude and Fratzscher (2008) also report pecking orders of international capital flows, and they included debt securities and loans separately as well as FDI and portfolio equity. Their pecking orders, however, do not list the various investment flows in terms of preference. They found that FDI and to some extent loans are more sensitive to information frictions than portfolio and debt. On the other hand, portfolio equity and debt are more responsive to differences in market development and host country institutional quality. From these results they infer that FDI may serve as an indicator of weak institutions.

Ostry et al. (2010) investigated the impact of capital controls on the severity of the global financial crisis, and they ranked capital inflows in terns of their volatility and impact on financial fragility. FDI is viewed as the least risky, followed by portfolio equity investment. The various forms of debt are more risky, beginning with debt denominated in the domestic currency, followed by domestic currency debt that is indexed by the Consumer Price Index. The debt seen as most risky is debt denominated in a foreign currency. Their results are similar to those of Levchenko and Mauro (2007) and Furceri, Guichard and Rusticelli (2012). 
Our pecking order, therefore, supports that of Ostry et al. (2010). Other criteria provide different rankings, and countries may have other goals that determine their rankings of capital flows. But the actual pattern of capital inflows during recent decades indicates that this order is the one preferred by many emerging market countries.

\section{Conclusions and Extensions}

Our results show that the composition of a country's external balance had a significant impact on how it fared during the global financial crisis, as Lane (2013) and others have claimed. The "long debt (and foreign reserves), short equity" external profile of many emerging markets did serve as a countercyclical buffer against the impact of the crisis in various ways. Those advanced and emerging market economies with the opposite configuration of external assets and liabilities fared worse, as this composition had a procyclical impact.

One extension of this research would be to investigate the determinants of the composition of the external balance sheets of emerging market countries. As noted above, some authors link the increased use of equity liabilities to improved institutional quality and greater financial development. However, Daude and Fratzscher (2008) found a different linkage between FDI and institutional quality. Separating FDI and portfolio equity in empirical analyses may reveal other differences in the characteristics associated with their use.

Another issue that merits investigation is the role of governments - if any-in managing the configuration of foreign funds through the use of capital controls. Lane and Schmukler (2007), for example, pointed out that the governments of China and India steered foreign investors into equity investments, FDI in the case of China and portfolio equity in India. Such a 
strategy would be consistent with the general improvement in economic policies noted by the IMF (2012) and others.

Montiel and Reinhart (1999) demonstrated that the use of capital controls would not change the volume of capital inflows, but could influence their composition. Campion and Neumann $(2003,2004)$ report evidence from Latin America that the use of controls did effect the composition of capital inflows. Klein (2012), however, investigated whether governments used controls to arrange capital inflows in a manner consistent with the pecking order described by Ostry et al. (2010), and found little evidence that controls were used for this purpose. This remains an open area of research.

More work can be done on the mechanisms of international risk-sharing. The returns on equity include investment income as well as capital gains. Bracke and Schmitz (2011) found that capital gains were more important than investment income as a channel of risk-sharing. ${ }^{17}$ Habib (2010), on the other hand, has claimed that cumulated investment income balances have a stronger influence than valuation changes on net external positions over time. Our results suggest that the cyclicality of the returns due to the composition of the balance sheet affects their role in their risk-sharing properties, and this topic also merits more analysis.

Finally, the configuration of external assets and liabilities as well as the size of global capital flows may be changing. Capital flows from the emerging markets, including FDI and bank loans, have risen. China's outward FDI has increased, for example, while its government has relaxed controls on foreign borrowing. ${ }^{18}$ Over time these patterns will alter the stocks of assets and liabilities of emerging markets, and may raise their vulnerability to external shocks. 


\section{NOTES}

${ }^{1}$ Didier, Hevia and Schmukler (2012) offer an analysis of the economic performance of ${ }^{2}$ Eichengreen and Hausmann (2005) pointed out that debt issued by emerging market firms and governments to foreign investors was often denominated in a foreign currency, usually the dollar, to assuage fears of currency depreciation. Hale, Jones and Spiegel (2014) have shown that the share of international bonds issued by firms denominated in their domestic currencies has risen over time. But Chui, Fender and Sushko (2014) claim that a significant amount of the recent debt of corporations in emerging market nations was issued through their foreign subsidiaries in offshore markets and denominated in foreign currencies.

${ }^{3}$ Quadrini and Ríos-Rull (2009), Devereux and Sutherland (2009) and Mendoza and Smith (2009) develop theoretical models to explain the difference in the composition of external assets and liabilities of the advanced and emerging economies.

${ }^{4}$ Hutchison and Noy $(2002,2005)$ find output costs of 5-8\% of GDP resulting from currency crises in emerging markets, which they attribute in part to wealth changes.

${ }^{5}$ There are also studies of how holdings of international reserves affected performance during the crisis. See Aizenman and Sun (2012), Dominguez, Hashimoto and Ito (2012), and Bussière et al. (2015).

${ }^{6}$ We relied on the October 2007 edition of the IMF's World Economic Outlook for the classification of the economies.

${ }^{7}$ The dataset is available at: http://www.philiplane.org/EWN.html

${ }^{8}$ Frankel and Saravelos (2012) used six indicators of crisis incidence in their study of the 200809 crisis, including the change in GDP and the use of IMF credit. 
${ }^{9}$ The studies cited in note \#2 and others report different findings regarding the significance of foreign reserves during the GFC. The specifications of the variable and the estimating equation affect the results.

${ }^{10}$ The World Economic Outlook is published twice a year, in April and October.

${ }^{11}$ Lipsey (2001) examined capital flows and the performance of U.S. affiliated firms during the Latin American debt crisis of 1980s, the Mexican crisis of 1994-95, and the Asian crisis of 199798. He found that direct investment inflows into the crisis countries were more stable than other types of flows, and that U.S. manufacturing affiliates increased their exports in the wake of the crises more quickly than did domestic firms.

${ }^{12}$ Kauko (2014) provides a recent survey of the empirical literature on banking crises.

${ }^{13}$ Laeven and Valencia (2013) define a bank crisis is defined as systemic if there are "significant signs of financial distress in the banking system" and "significant banking policy interventions in response to significant losses in the banking system."

14 These were all Stand-by Arrangements. We did not include the Flexible Credit Lines as no credit was drawn through these. See Joyce (2012) for an account of the IMF's activities before and during the global financial crisis.

${ }^{15}$ Sturm, Berger and de Haan (2005) review the economic and political factors that appeared in previous studies of the determinants of Fund programs.

${ }^{16}$ The variable takes of the value of one if a country's exchange rate regime ranges between 1 8 on the Reinhart-Rogoff (2004) scale of exchange rate regimes that has a total range of $1-13$, Higher numbers denote more flexible regimes.

${ }^{17}$ See also Schmitz $(2010,2013)$.

${ }^{18}$ See He et. al (2012) 


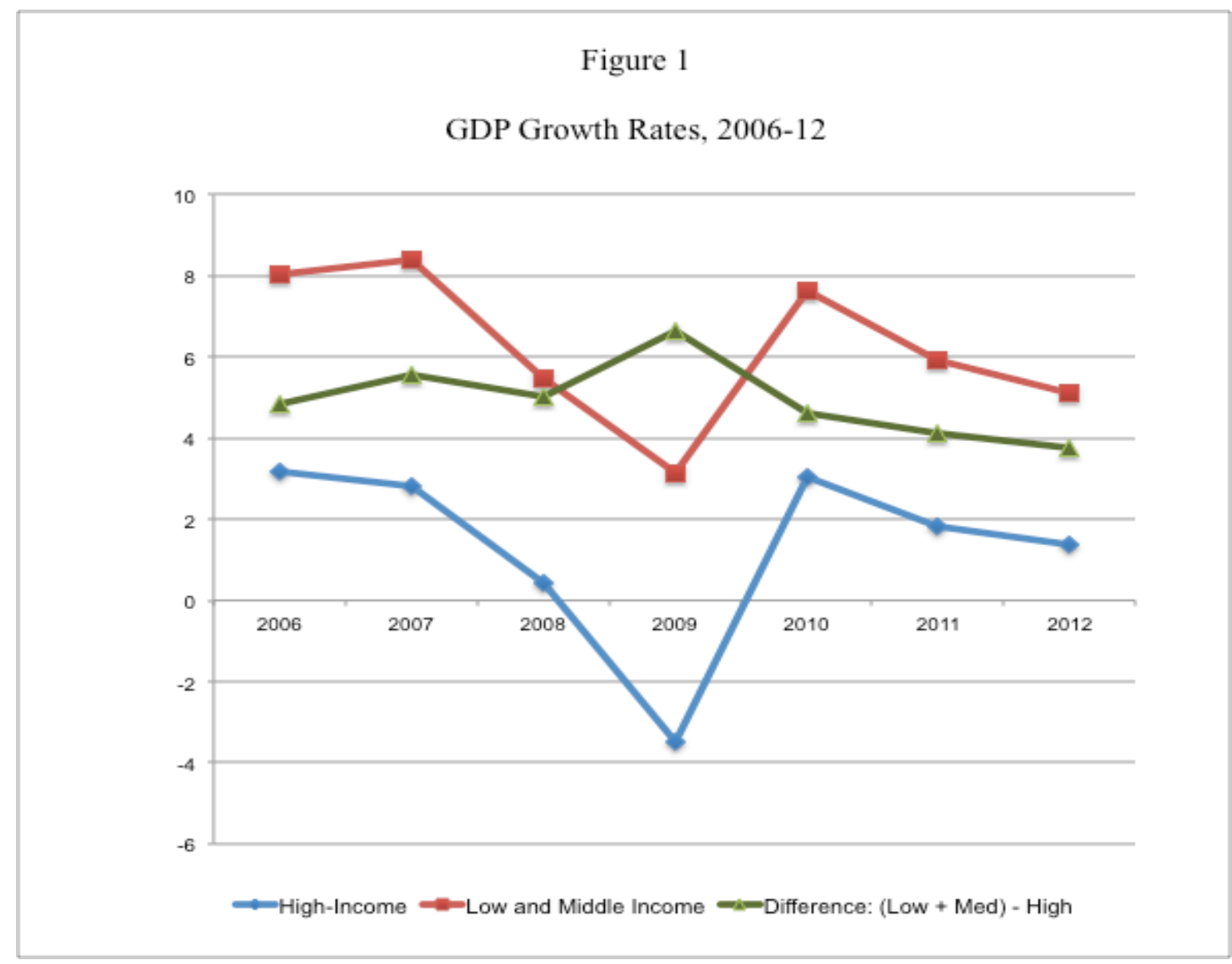

Figure 2

External Balance Sheet

\begin{tabular}{l|l}
\hline \multicolumn{1}{c|}{ Assets } & Liabilities \\
\hline Equity (FDI, Portfolio) $^{\mathrm{F}}$ & Equity (FDI, Portfolio) $^{\mathrm{D}}$ \\
\hline + Debt (Bonds, Bank Loans) $^{\mathrm{F}}$ & + Debt (Bonds, Bank Loans) \\
\hline + Foreign Exchange Reserves $^{\mathrm{F}}$ & \\
\hline
\end{tabular}

Foreign Assets of Domestic Residents - Domestic Liabilities of Foreign Residents $=$

Net International Investment Position (+ creditor, - debtor)

Note: F identifies assets and liabilities denominated in foreign currency, D denominated in domestic currency, F/D denominated in foreign or domestic currency. 
Figure 3

Equity/Debt Liabilities (2007)

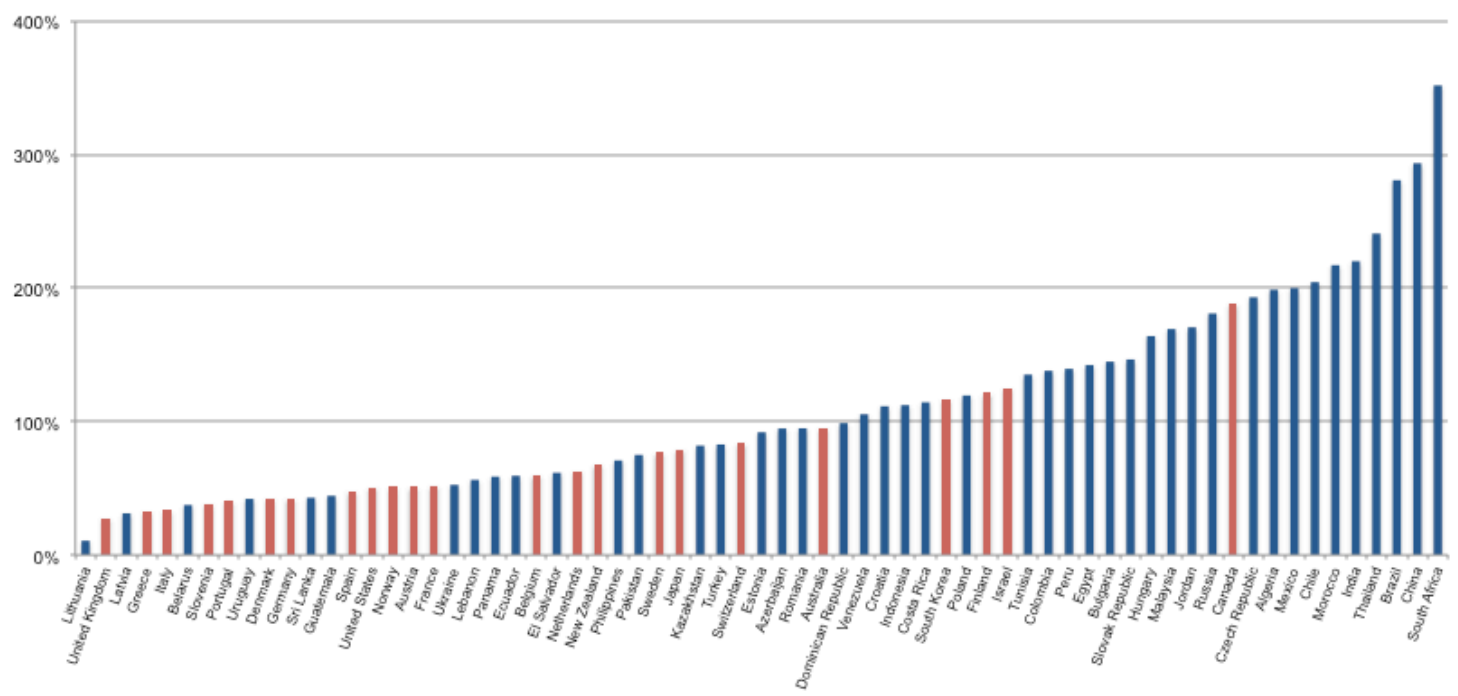

Figure 4

GDP Growth Rates (2008-09)

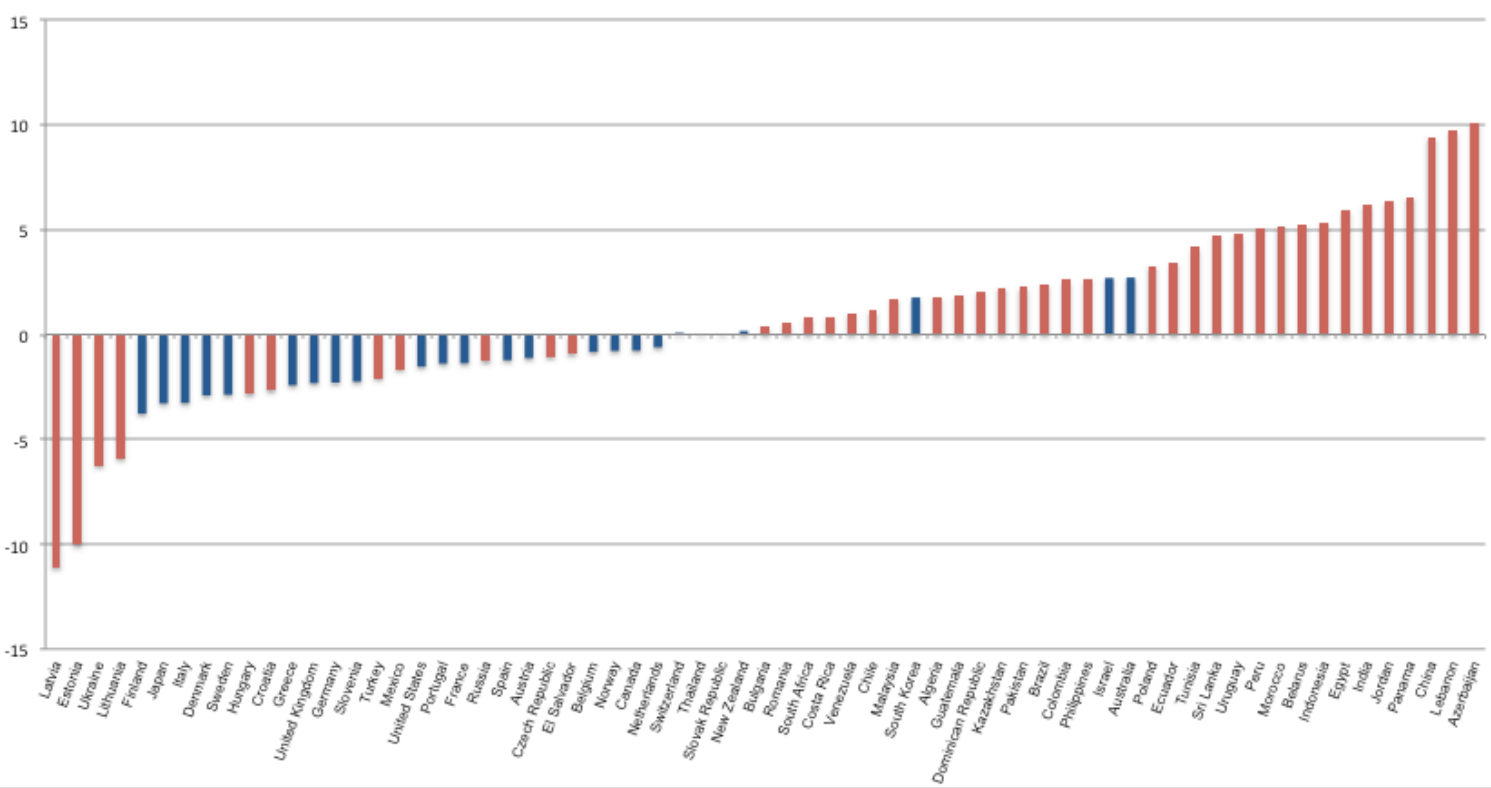




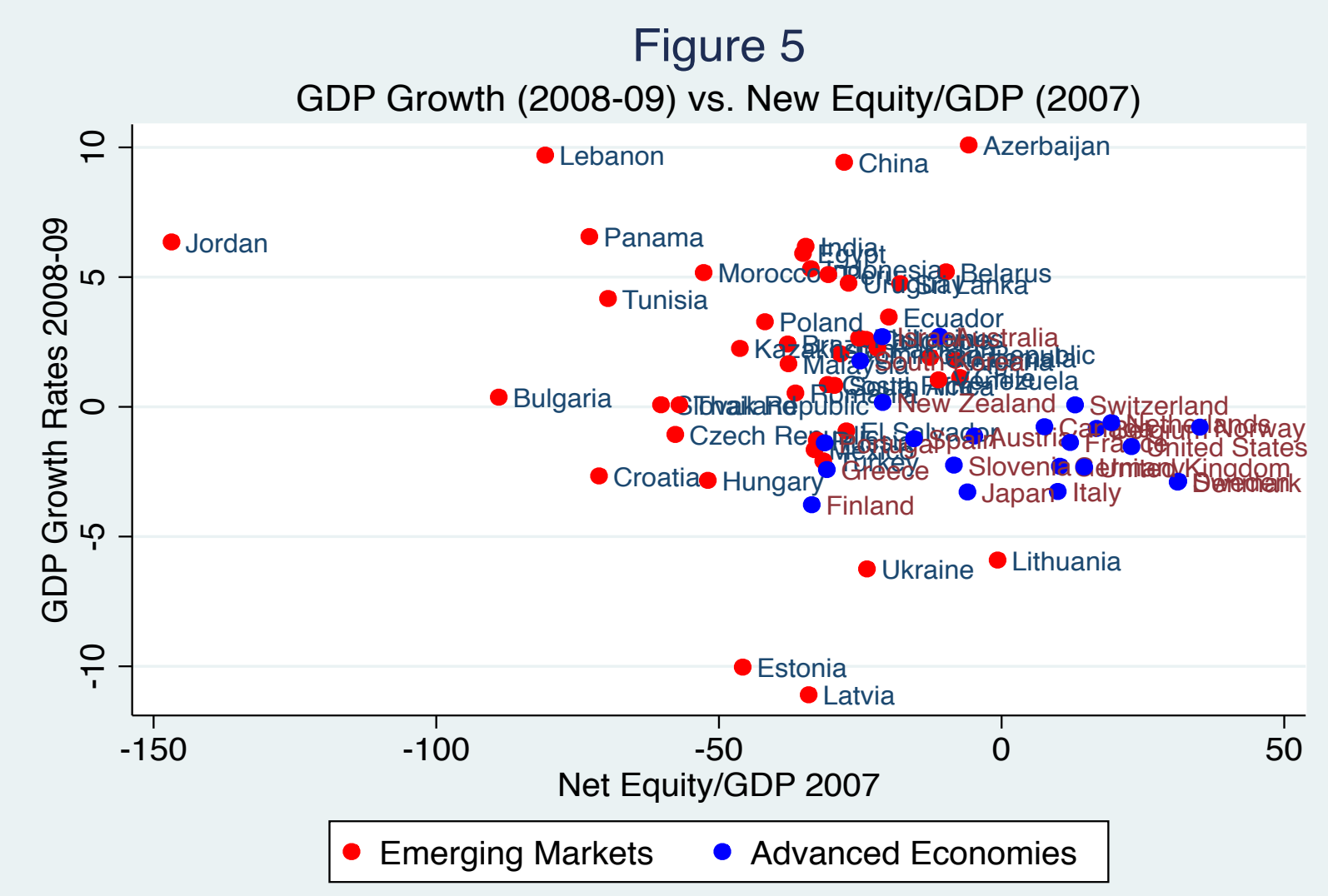

Figure 6

International Pecking Orders

\begin{tabular}{l|ccc}
\hline Authors & First & Second & Third \\
\hline Razin, Sadka and Yuen (1998) & FDI & Portfolio Debt & Portfolio Equity \\
Reisen and Soto (2001) & Portfolio Equity & FDI & Debt \\
Ostry et al. (2010) & FDI & Portfolio Equity & Debt \\
\hline
\end{tabular}


Table 1

Average GDP Growth (2008-09) and External Assets and Liabilities: Full Sample

\begin{tabular}{|c|c|c|c|c|c|c|}
\hline & $(1.1)$ & $(1.2)$ & $(1.3)$ & $(1.4)$ & $(1.5)$ & $(1.6)$ \\
\hline \multirow[t]{2}{*}{ Cur Act/Y } & $0.20 * * *$ & $0.22 * * *$ & $0.20 * * *$ & $0.20 * * *$ & $0.11 * *$ & $0.12 * *$ \\
\hline & $(0.06)$ & $(0.06)$ & $(0.06)$ & $(0.06)$ & $(0.05)$ & $(0.06)$ \\
\hline \multirow[t]{2}{*}{$\Delta \mathrm{Dm} \mathrm{Cr} / \mathrm{Y}$} & $-0.05^{*}$ & $-0.04^{*}$ & -0.03 & -0.03 & $-0.05^{*}$ & $-0.04^{*}$ \\
\hline & $(0.02)$ & $(0.02)$ & $(0.02)$ & $(0.02)$ & $(0.02)$ & $(0.02)$ \\
\hline \multirow[t]{2}{*}{ Y/Pop } & $-3.44 * * *$ & $-2.77 * * *$ & $-2.66 * * *$ & $-2.94 * * *$ & $-3.20 * * *$ & $-3.64 * * *$ \\
\hline & $(0.70)$ & $(0.76)$ & $(0.75)$ & $(0.73)$ & $(0.82)$ & $(0.74)$ \\
\hline \multirow[t]{2}{*}{ Trad Open/Y } & -0.01 & -0.02 & $-0.02 *$ & -0.02 & -0.00 & -0.00 \\
\hline & $(0.01)$ & $(0.01)$ & $(0.01)$ & $(0.01)$ & $(0.01)$ & $(0.01)$ \\
\hline \multirow[t]{2}{*}{ Fin Open/Y } & 0.00 & 0.00 & $0.00^{*}$ & 0.00 & 0.00 & 0.00 \\
\hline & $(0.00)$ & $(0.00)$ & $(0.00)$ & $(0.00)$ & $(0.00)$ & $(0.01)$ \\
\hline \multirow[t]{2}{*}{ NIIP/Y } & $-0.03 * *$ & & & & & \\
\hline & $(0.01)$ & $-0.06 * * *$ & & & & \\
\hline Net Eq/Y & & $(0.02)$ & & & & \\
\hline \multirow[t]{2}{*}{ Net Dbt/Y } & & -0.01 & & & & \\
\hline & & $(0.01)$ & & & & \\
\hline \multirow[t]{2}{*}{ For Res/Y } & & -0.03 & & & & \\
\hline & & $(0.03)$ & & & & \\
\hline \multirow[t]{2}{*}{ Net FDI/Y } & & & $-0.07 * * *$ & & & \\
\hline & & & $(0.02)$ & & & \\
\hline \multirow[t]{2}{*}{ Net Prt/Y } & & & -0.04 & & & \\
\hline & & & $(0.02)$ & & & \\
\hline \multirow[t]{2}{*}{ FDI Ast/Y } & & & & $-0.07 * *$ & & \\
\hline & & & & $(0.03)$ & & \\
\hline \multirow[t]{2}{*}{ FDI Lbt/Y } & & & & $0.05 * *$ & & \\
\hline & & & & $(0.02)$ & & \\
\hline \multirow[t]{2}{*}{ Prt Ast/Y } & & & & & -0.04 & \\
\hline & & & & & $(0.04)$ & \\
\hline \multirow[t]{2}{*}{$\operatorname{Prt} \mathrm{Lbt} / \mathrm{Y}$} & & & & & 0.01 & \\
\hline & & & & & $(0.03)$ & \\
\hline \multirow[t]{2}{*}{ Dbt Ast/Y } & & & & & & -0.02 \\
\hline & & & & & & $(0.02)$ \\
\hline \multirow[t]{2}{*}{ Dbt Lbt/Y } & & & & & & 0.01 \\
\hline & & & & & & $(0.02)$ \\
\hline \multirow[t]{2}{*}{ Constant } & $34.23 * * *$ & $27.93 * * *$ & $26.92 * * *$ & $29.75 * * *$ & $32.47 * * *$ & $36.32 * * *$ \\
\hline & $(6.63)$ & $(7.23)$ & $(7.15)$ & $(7.00)$ & $(7.71)$ & $(6.92)$ \\
\hline Adjusted $\mathrm{R}^{2}$ & 0.43 & 0.46 & 0.46 & 0.44 & 0.38 & 0.38 \\
\hline $\mathrm{N}$ & 67 & 67 & 67 & 67 & 67 & 67 \\
\hline
\end{tabular}

Note: See text for variable definitions. $*, * *, * * *$ denote $10 \%, 5 \%$ and $1 \%$ levels of significance 
Table 2

Average GDP Growth (2008-09) and External Assets and Liabilities:

Emerging Markets

\begin{tabular}{|c|c|c|c|c|c|c|}
\hline & $(2.1)$ & $(2.2)$ & $(2.3)$ & $(2.4)$ & $(2.5)$ & $(2.6)$ \\
\hline \multirow[t]{2}{*}{ Cur Act/Y } & $0.15^{*}$ & $0.15^{*}$ & $0.18 * *$ & $0.19 * *$ & 0.08 & 0.06 \\
\hline & (0.09) & $(0.08)$ & $(0.07)$ & $(0.07)$ & $(0.07)$ & $(0.08)$ \\
\hline \multirow[t]{2}{*}{$\Delta \mathrm{Dm} \mathrm{Cr} / \mathrm{Y}$} & $-0.15^{* *}$ & $-0.14 * *$ & $-0.14 * *$ & $-0.13^{* *}$ & $-0.17 * * *$ & $-0.17 * * *$ \\
\hline & $(0.06)$ & $(0.05)$ & $(0.05)$ & $(0.05)$ & $(0.06)$ & $(0.06)$ \\
\hline \multirow[t]{2}{*}{ Y/Pop } & $-2.97 * *$ & $-2.58 *$ & $-2.71 * *$ & $-3.01 * *$ & $-2.86^{*}$ & $-3.22 * *$ \\
\hline & $(1.34)$ & $(1.30)$ & $(1.31)$ & $(1.27)$ & (1.44) & $(1.35)$ \\
\hline \multirow[t]{2}{*}{ Trad Open/Y } & -0.01 & -0.01 & -0.02 & -0.02 & -0.01 & -0.01 \\
\hline & $(0.02)$ & $(0.02)$ & $(0.02)$ & $(0.02)$ & $(0.02)$ & $(0.02)$ \\
\hline \multirow[t]{2}{*}{ Fin Open/Y } & 0.01 & 0.00 & -0.00 & 0.01 & 0.01 & 0.01 \\
\hline & $(0.01)$ & $(0.01)$ & $(0.01)$ & $(0.01)$ & $(0.01)$ & $(0.01)$ \\
\hline NIIP/Y & $\begin{array}{l}-0.02 \\
(0.02)\end{array}$ & & & & & \\
\hline Net Eq/Y & & $\begin{array}{l}-0.07 * * \\
(0.03)\end{array}$ & & & & \\
\hline Net Dbt/Y & & $\begin{array}{c}0.02 \\
(0.03)\end{array}$ & & & & \\
\hline For Res/Y & & $\begin{array}{l}-0.03 \\
(0.04)\end{array}$ & & & & \\
\hline Net FDI/Y & & & $\begin{array}{l}-0.09^{* *} \\
(0.03)\end{array}$ & & & \\
\hline Net Prt/Y & & & $\begin{array}{l}-0.04 \\
(0.04)\end{array}$ & & & \\
\hline FDI Ast/Y & & & & $\begin{array}{l}-0.10^{* *} \\
(0.04)\end{array}$ & & \\
\hline FDI Lbt/Y & & & & $\begin{array}{c}0.07^{*} \\
(0.04)\end{array}$ & & \\
\hline Prt Ast/Y & & & & & $\begin{array}{l}-0.01 \\
(0.08)\end{array}$ & \\
\hline Prt Lbt/Y & & & & & $\begin{array}{c}0.03 \\
(0.05)\end{array}$ & \\
\hline Dbt Ast/Y & & & & & & $\begin{array}{c}0.04 \\
(0.04)\end{array}$ \\
\hline DbtLbt/Y & & & & & & $\begin{array}{l}-0.03 \\
(0.04)\end{array}$ \\
\hline Constant & $\begin{array}{c}30.34 * * \\
(11.77) \\
\end{array}$ & $\begin{array}{c}26.69^{* *} \\
(11.50)\end{array}$ & $\begin{array}{c}27.56^{* *} \\
(11.54)\end{array}$ & $\begin{array}{c}30.17 * * \\
(11.13)\end{array}$ & $\begin{array}{l}29.40 * * \\
(12.63)\end{array}$ & $\begin{array}{l}32.75^{* * * *} \\
(11.81)\end{array}$ \\
\hline Adjusted $\mathrm{R}^{2}$ & 0.47 & 0.53 & 0.54 & 0.53 & 0.45 & 0.46 \\
\hline $\mathrm{N}$ & 44 & 44 & 44 & 44 & 44 & 44 \\
\hline
\end{tabular}

Note: See text for variable definitions. $*, * *, * *$ denote $10 \%, 5 \%$ and $1 \%$ levels of significance 
Table 3

Difference in Average and Projected GDP Growth (2008-09) and External Assets and Liabilities: Full Sample

\begin{tabular}{|c|c|c|c|c|c|c|}
\hline & $(3.1)$ & $(3.2)$ & $(3.3)$ & (3.4) & $(3.5)$ & (3.6) \\
\hline \multirow[t]{2}{*}{ Cur Act/Y } & 0.07 & 0.09 & 0.08 & 0.07 & 0.01 & 0.02 \\
\hline & $(0.06)$ & $(0.06)$ & $(0.05)$ & $(0.05)$ & $(0.05)$ & $(0.05)$ \\
\hline \multirow[t]{2}{*}{$\Delta \mathrm{Dm} \mathrm{Cr} / \mathrm{Y}$} & $-0.05 * *$ & $-0.05 * *$ & $-0.04 * *$ & $-0.04^{*}$ & $-0.05 * *$ & $-0.05^{* *}$ \\
\hline & $(0.02)$ & $(0.02)$ & $(0.02)$ & $(0.02)$ & $(0.02)$ & $(0.02)$ \\
\hline \multirow[t]{2}{*}{ Y/Pop } & $-1.60 * *$ & -1.09 & -1.08 & $-1.34^{*}$ & $-1.60 * *$ & $-1.77 * * *$ \\
\hline & $(0.63)$ & $(0.70)$ & $(0.69)$ & $(0.67)$ & $(0.73)$ & $(0.66)$ \\
\hline \multirow[t]{2}{*}{ Trad Open/Y } & $-0.02 * *$ & $-0.03 * * *$ & $-0.04 * * *$ & $-0.03 * * *$ & $-0.02 *$ & $-0.02 * *$ \\
\hline & $(0.01)$ & $(0.01)$ & $(0.01)$ & $(0.01)$ & $(0.01)$ & $(0.01)$ \\
\hline \multirow[t]{2}{*}{ Fin Open/Y } & $0.01 * * *$ & $0.01 * * *$ & $0.01 * * *$ & $0.01 *$ & 0.00 & 0.01 \\
\hline & $(0.00)$ & $(0.00)$ & $(0.00)$ & $(0.00)$ & $(0.00)$ & $(0.01)$ \\
\hline \multirow[t]{2}{*}{ NIIP/Y } & $-0.02 *$ & & & & & \\
\hline & $(0.01)$ & & & & & \\
\hline \multirow[t]{2}{*}{ Net Eq/Y } & & $-0.04 * *$ & & & & \\
\hline & & $(0.02)$ & & & & \\
\hline \multirow[t]{2}{*}{ Net Dbt/Y } & & -0.01 & & & & \\
\hline & & $(0.01)$ & & & & \\
\hline \multirow[t]{2}{*}{ For Res/Y } & & -0.02 & & & & \\
\hline & & $(0.03)$ & & & & \\
\hline \multirow{2}{*}{ Net FDI/Y } & & & $-0.04 * *$ & & & \\
\hline & & & $(0.02)$ & & & \\
\hline \multirow[t]{2}{*}{ Net Prt/Y } & & & -0.02 & & & \\
\hline & & & $(0.02)$ & & & \\
\hline \multirow[t]{2}{*}{ FDI Ast/Y } & & & & -0.03 & & \\
\hline & & & & $(0.03)$ & & \\
\hline \multirow[t]{2}{*}{ FDI Lbt/Y } & & & & $0.04^{*}$ & & \\
\hline & & & & $(0.02)$ & & \\
\hline \multirow[t]{2}{*}{$\operatorname{Prt}$ Ast/Y } & & & & & -0.01 & \\
\hline & & & & & $(0.04)$ & \\
\hline \multirow[t]{2}{*}{ Prt Lbt/Y } & & & & & 0.01 & \\
\hline & & & & & $(0.02)$ & \\
\hline \multirow[t]{2}{*}{ Dbt Ast/Y } & & & & & & -0.02 \\
\hline & & & & & & $(0.02)$ \\
\hline \multirow[t]{2}{*}{$\mathrm{Dbt} \mathrm{Lbt} / \mathrm{Y}$} & & & & & & 0.00 \\
\hline & & & & & & $(0.02)$ \\
\hline \multirow[t]{2}{*}{ Constant } & $12.71 * *$ & 7.87 & 7.88 & 10.61 & $13.03 *$ & $14.39 * *$ \\
\hline & $(6.02)$ & $(6.64)$ & $(6.60)$ & $(6.41)$ & $(6.93)$ & $(6.16)$ \\
\hline Adjusted $\mathrm{R}^{2}$ & 0.22 & 0.24 & 0.23 & 0.22 & 0.17 & 0.19 \\
\hline $\mathrm{N}$ & 67 & 67 & 67 & 67 & 67 & 67 \\
\hline
\end{tabular}

Note: See text for variable definitions. $*, * *, * * *$ denote $10 \%, 5 \%$ and $1 \%$ levels of significance 
Table 4

Bank Crises and External Assets and Liabilities

\begin{tabular}{|c|c|c|c|c|c|c|}
\hline & $(4.1)$ & $(4.2)$ & $(4.3)$ & $(4.4)$ & $(4.5)$ & $(4.6)$ \\
\hline \multirow[t]{2}{*}{$\Delta$ Dom $\mathrm{Cr} / \mathrm{Y}$} & $0.13 *$ & $0.16^{*}$ & $0.16^{* *}$ & $0.09 *$ & $0.05^{* *}$ & $0.05^{*}$ \\
\hline & $(0.07)$ & $(0.09)$ & $(0.08)$ & $(0.05)$ & $(0.03)$ & $(0.03)$ \\
\hline \multirow[t]{2}{*}{ Y/Pop } & $5.25 *$ & $5.42 *$ & $5.05 *$ & $4.52 *$ & 4.45 & 5.27 \\
\hline & $(2.84)$ & (3.14) & $(2.80)$ & (2.69) & $(2.78)$ & $(3.27)$ \\
\hline \multirow[t]{2}{*}{$\% \Delta \mathrm{Y}$} & -0.74 & -0.76 & $-0.42 *$ & $-0.43 *$ & -0.41 & -0.27 \\
\hline & $(0.45)$ & $(0.50)$ & $(0.23)$ & $(0.25)$ & $(0.27)$ & $(0.18)$ \\
\hline \multirow[t]{2}{*}{$\% \Delta \mathrm{P}$} & $0.95 * *$ & $1.13^{*}$ & $1.04 * *$ & $0.82 * *$ & $0.75^{*}$ & $0.88^{*}$ \\
\hline & $(0.48)$ & $(0.58)$ & $(0.50)$ & $(0.40)$ & $(0.41)$ & $(0.48)$ \\
\hline \multirow[t]{2}{*}{ Fin Open/Y } & $0.01 *$ & $0.01 *$ & 0.01 & $0.01 * *$ & $0.01 *$ & -0.01 \\
\hline & $(0.00)$ & $(0.01)$ & $(0.01)$ & $(0.00)$ & $(0.01)$ & $(0.01)$ \\
\hline NIIP/Y & $\begin{array}{c}0.03^{*} \\
0.01)\end{array}$ & & & & & \\
\hline Net Eq/Y & & $\begin{array}{c}0.08^{*} \\
(0.05)\end{array}$ & & & & \\
\hline Net Dbt/Y & & $\begin{array}{c}0.01 \\
(0.02)\end{array}$ & & & & \\
\hline For Res/Y & & $\begin{array}{c}0.06 \\
(0.06)\end{array}$ & & & & \\
\hline Net FDI/Y & & & $\begin{array}{c}0.10^{*} \\
(0.06)\end{array}$ & & & \\
\hline Net Prt/Y & & & $\begin{array}{l}0.08^{*} \\
(0.04)\end{array}$ & & & \\
\hline FDI Lbt/Y & & & & $\begin{array}{l}-0.03 * \\
(0.02)\end{array}$ & & \\
\hline $\operatorname{Prt} \mathrm{Lbt} / \mathrm{Y}$ & & & & & $\begin{array}{l}-0.04 \\
(0.03)\end{array}$ & \\
\hline $\mathrm{Dbt} \mathrm{Lbt} / \mathrm{Y}$ & & & & & & $\begin{array}{r}0.05^{*} \\
(0.03)\end{array}$ \\
\hline Constant & $\begin{array}{l}-57.53^{*} \\
(29.92) \\
\end{array}$ & $\begin{array}{l}-61.40^{*} \\
(33.83) \\
\end{array}$ & $\begin{array}{l}-57.80^{*} \\
(30.73) \\
\end{array}$ & $\begin{array}{l}-50.61 * \\
(28.83) \\
\end{array}$ & $\begin{array}{l}-49.90 * \\
(29.80) \\
\end{array}$ & $\begin{array}{l}-60.40^{*} \\
(35.65) \\
\end{array}$ \\
\hline Pseudo $\mathrm{R}^{2}$ & 0.78 & 0.81 & 0.82 & 0.77 & 0.76 & 0.79 \\
\hline $\mathrm{N}$ & 64 & 64 & 64 & 64 & 64 & 64 \\
\hline
\end{tabular}

Note: See text for variable definitions. $* * *, * * *$ denote $10 \%, 5 \%$ and $1 \%$ levels of significance 
Table 5

IMF Programs and External Assets and Liabilities

\begin{tabular}{|c|c|c|c|c|c|c|}
\hline & $(5.1)$ & $(5.2)$ & $(5.3)$ & $(5.4)$ & $(5.5)$ & $(5.6)$ \\
\hline Cur Act/Y & $\begin{array}{l}-0.11^{* *} \\
(0.05)\end{array}$ & $\begin{array}{l}-0.19 * * \\
(0.08)\end{array}$ & $\begin{array}{l}-0.17 * * \\
(0.08)\end{array}$ & $\begin{array}{l}-0.26^{* *} \\
(0.12)\end{array}$ & $\begin{array}{l}-0.06 \\
(0.04)\end{array}$ & $\begin{array}{l}-0.08 * * \\
(0.04)\end{array}$ \\
\hline$\Delta$ Dom $\mathrm{Cr} / \mathrm{Y}$ & $\begin{array}{l}-0.02 \\
(0.03)\end{array}$ & $\begin{array}{l}-0.05 \\
(0.04)\end{array}$ & $\begin{array}{l}-0.02 \\
(0.03)\end{array}$ & $\begin{array}{l}-0.05 \\
(0.04)\end{array}$ & $\begin{array}{c}0.02 \\
(0.04)\end{array}$ & $\begin{array}{l}-0.02 \\
(0.04)\end{array}$ \\
\hline $\mathrm{Pop} / \mathrm{Y}$ & $\begin{array}{l}-0.85 \\
(0.67)\end{array}$ & $\begin{array}{l}-1.86^{*} \\
(1.00)\end{array}$ & $\begin{array}{l}-1.70^{*} \\
(0.94)\end{array}$ & $\begin{array}{l}-1.31 \\
(0.82)\end{array}$ & $\begin{array}{l}-1.83 * \\
(1.04)\end{array}$ & $\begin{array}{l}-0.91 \\
(0.80)\end{array}$ \\
\hline$\% \Delta \mathrm{P}$ & $\begin{array}{l}0.25^{* *} \\
(0.11)\end{array}$ & $\begin{array}{l}0.53^{* *} \\
(0.25)\end{array}$ & $\begin{array}{l}0.32 * * \\
(0.16)\end{array}$ & $\begin{array}{l}0.48^{* *} \\
(0.23)\end{array}$ & $\begin{array}{r}0.20^{*} \\
(0.11)\end{array}$ & $\begin{array}{l}0.32 * * \\
(0.13)\end{array}$ \\
\hline Gov/Y & $\begin{array}{c}0.00 \\
(0.08)\end{array}$ & $\begin{array}{l}-0.04 \\
(0.11)\end{array}$ & $\begin{array}{c}0.04 \\
(0.09)\end{array}$ & $\begin{array}{l}-0.08 \\
(0.10)\end{array}$ & $\begin{array}{c}0.05 \\
(0.09)\end{array}$ & $\begin{array}{l}-0.03 \\
(0.09)\end{array}$ \\
\hline Fix & $\begin{array}{l}-0.29 \\
(0.60)\end{array}$ & $\begin{array}{l}-0.42 \\
(0.77)\end{array}$ & $\begin{array}{l}-0.53 \\
(0.76)\end{array}$ & $\begin{array}{c}0.07 \\
(0.74)\end{array}$ & $\begin{array}{l}-0.85 \\
(0.76)\end{array}$ & $\begin{array}{l}-0.10 \\
(0.66)\end{array}$ \\
\hline $\mathrm{NIIP} / \mathrm{Y}$ & $\begin{array}{c}0.01 \\
(0.01)\end{array}$ & & & & & \\
\hline Net Eq/Y & & $\begin{array}{c}0.05^{*} \\
(0.03)\end{array}$ & & & & \\
\hline Net Dbt/Y & & $\begin{array}{l}-0.05 \\
(0.03)\end{array}$ & & & & \\
\hline For Res/Y & & $\begin{array}{l}-0.03 \\
(0.06)\end{array}$ & & & & \\
\hline Net FDI/Y & & & $\begin{array}{c}0.05^{*} \\
(0.03)\end{array}$ & & & \\
\hline Net Prt/Y & & & $\begin{array}{c}0.08^{*} \\
(0.04)\end{array}$ & & & \\
\hline FDI Ast/Y & & & & $\begin{array}{l}0.08 * * \\
(0.04)\end{array}$ & & \\
\hline FDI Lbt/Y & & & & $\begin{array}{l}-0.06^{*} \\
(0.03)\end{array}$ & & \\
\hline Port Ast/Y & & & & & $\begin{array}{c}0.03 \\
(0.10)\end{array}$ & \\
\hline Port Lbt/Y & & & & & $\begin{array}{l}-0.11 \\
(0.07)\end{array}$ & \\
\hline Debt Ast/Y & & & & & & $\begin{array}{l}-0.04 \\
(0.03)\end{array}$ \\
\hline Debt Lbt/Y & & & & & & $\begin{array}{c}0.03 \\
(0.02)\end{array}$ \\
\hline Constant & $\begin{array}{r}5.66 \\
(6.03) \\
\end{array}$ & $\begin{array}{l}13.99 \\
(8.73) \\
\end{array}$ & $\begin{array}{l}13.60 \\
(8.57)\end{array}$ & $\begin{array}{c}9.36 \\
(7.46) \\
\end{array}$ & $\begin{array}{l}14.98 \\
(9.39) \\
\end{array}$ & $\begin{array}{c}5.58 \\
(7.09) \\
\end{array}$ \\
\hline $\begin{array}{l}\text { Pseudo } \mathrm{R}^{2} \\
\mathrm{~N}\end{array}$ & $\begin{array}{l}0.35 \\
64 \\
\end{array}$ & $\begin{array}{l}0.70 \\
64 \\
\end{array}$ & $\begin{array}{l}0.52 \\
64 \\
\end{array}$ & $\begin{array}{l}0.53 \\
64 \\
\end{array}$ & $\begin{array}{l}0.35 \\
64 \\
\end{array}$ & $\begin{array}{l}0.46 \\
64\end{array}$ \\
\hline
\end{tabular}

Note: See text for variable definitions. $*, * *, * * *$ denote $10 \%, 5 \%$ and $1 \%$ levels of significance 
Table 6

IMF Programs (Extended) and External Assets and Liabilities

\begin{tabular}{|c|c|c|c|c|c|c|}
\hline & $(6.1)$ & $(6.2)$ & $(6.3)$ & $(6.4)$ & $(6.5)$ & $(6.6)$ \\
\hline Cur Act/Y & $\begin{array}{l}-0.09 * * \\
(0.04)\end{array}$ & $\begin{array}{l}-0.25 * * \\
(0.11)\end{array}$ & $\begin{array}{l}-0.22 * * * \\
(0.08)\end{array}$ & $\begin{array}{l}-0.25 * * * \\
(0.09)\end{array}$ & $\begin{array}{l}-0.09 * * \\
(0.04)\end{array}$ & $\begin{array}{l}-0.07 * * \\
(0.04)\end{array}$ \\
\hline$\Delta$ Dom $\mathrm{Cr} / \mathrm{Y}$ & $\begin{array}{l}-0.02 \\
(0.02)\end{array}$ & $\begin{array}{l}-0.06^{*} \\
(0.03)\end{array}$ & $\begin{array}{l}-0.03 \\
(0.02)\end{array}$ & $\begin{array}{l}-0.04 * \\
(0.02)\end{array}$ & $\begin{array}{l}-0.02 \\
(0.02)\end{array}$ & $\begin{array}{l}-0.04 \\
(0.03)\end{array}$ \\
\hline Pop/Y & $\begin{array}{l}-0.37 \\
(0.51)\end{array}$ & $\begin{array}{l}-2.45^{* *} \\
(1.18)\end{array}$ & $\begin{array}{l}-1.12 \\
(0.80)\end{array}$ & $\begin{array}{l}-1.14 \\
(0.71)\end{array}$ & $\begin{array}{l}-0.43 \\
(0.60)\end{array}$ & $\begin{array}{l}-0.92 \\
(0.67)\end{array}$ \\
\hline$\% \Delta \mathrm{P}$ & $\begin{array}{l}0.16^{* *} \\
(0.08)\end{array}$ & $\begin{array}{l}0.56^{* *} \\
(0.23)\end{array}$ & $\begin{array}{c}0.20 \\
(0.13)\end{array}$ & $\begin{array}{c}0.25^{*} \\
(0.14)\end{array}$ & $\begin{array}{r}0.14^{*} \\
(0.08)\end{array}$ & $\begin{array}{l}0.29 * * \\
(0.12)\end{array}$ \\
\hline Gov/Y & $\begin{array}{l}-0.01 \\
(0.07)\end{array}$ & $\begin{array}{l}-0.04 \\
(0.11)\end{array}$ & $\begin{array}{c}0.05 \\
(0.09)\end{array}$ & $\begin{array}{c}0.01 \\
(0.08)\end{array}$ & $\begin{array}{c}0.01 \\
(0.07)\end{array}$ & $\begin{array}{l}-0.05 \\
(0.08)\end{array}$ \\
\hline Fix & $\begin{array}{c}0.04 \\
(0.50)\end{array}$ & $\begin{array}{l}-0.17 \\
(0.84)\end{array}$ & $\begin{array}{l}-0.03 \\
(0.58)\end{array}$ & $\begin{array}{c}0.16 \\
(0.62)\end{array}$ & $\begin{array}{c}0.03 \\
(0.50)\end{array}$ & $\begin{array}{l}-0.07 \\
(0.60)\end{array}$ \\
\hline NIIP/Y & $\begin{array}{l}-0.00 \\
(0.01)\end{array}$ & & & & & \\
\hline Net Eq/Y & & $\begin{array}{c}0.03 \\
(0.02)\end{array}$ & & & & \\
\hline Net Dbt/Y & & $\begin{array}{l}-0.06^{* *} \\
(0.03)\end{array}$ & & & & \\
\hline For Res/Y & & $\begin{array}{l}-0.16^{* *} \\
(0.07)\end{array}$ & & & & \\
\hline Net FDI/Y & & & $\begin{array}{l}0.05^{* *} \\
(0.02)\end{array}$ & & & \\
\hline Net Prt/Y & & & $\begin{array}{c}0.02 \\
(0.03)\end{array}$ & & & \\
\hline FDI Ast/Y & & & & $\begin{array}{l}0.07 * * \\
(0.03)\end{array}$ & & \\
\hline FDI Lbt/Y & & & & $\begin{array}{l}-0.05^{* *} \\
(0.02)\end{array}$ & & \\
\hline Prt Ast/Y & & & & & $\begin{array}{c}0.00 \\
(0.03)\end{array}$ & \\
\hline Prt Lbt/Y & & & & & $\begin{array}{l}-0.01 \\
(0.02)\end{array}$ & \\
\hline $\mathrm{Dbt}$ Ast/Y & & & & & & $\begin{array}{l}-0.04 * * \\
(0.02)\end{array}$ \\
\hline $\mathrm{Dbt} \mathrm{Lbt} / \mathrm{Y}$ & & & & & & $\begin{array}{l}0.05^{* *} \\
(0.02)\end{array}$ \\
\hline Constant & $\begin{array}{c}1.63 \\
(4.68)\end{array}$ & $\begin{array}{c}20.43^{*} \\
(10.80) \\
\end{array}$ & $\begin{array}{c}8.72 \\
(7.35)\end{array}$ & $\begin{array}{c}8.63 \\
(6.51) \\
\end{array}$ & $\begin{array}{c}2.26 \\
(5.50) \\
\end{array}$ & $\begin{array}{c}5.61 \\
(5.90) \\
\end{array}$ \\
\hline $\begin{array}{l}\text { Pseudo } \mathrm{R}^{2} \\
\mathrm{~N}\end{array}$ & $\begin{array}{l}0.35 \\
64\end{array}$ & $\begin{array}{l}0.70 \\
64\end{array}$ & $\begin{array}{l}0.52 \\
64\end{array}$ & $\begin{array}{l}0.53 \\
64\end{array}$ & $\begin{array}{l}0.35 \\
64\end{array}$ & $\begin{array}{l}0.46 \\
64\end{array}$ \\
\hline
\end{tabular}

Note: See text for variable definitions. $* * *, * * *$ denote $10 \%, 5 \%$ and $1 \%$ levels of significance 
Table 7

Average GDP Growth (2008-09) and External Assets and Liabilities with Eurozone

\begin{tabular}{|c|c|c|c|c|c|}
\hline & $(7.1)$ & $(7.2)$ & (7.3) & $(7.4)$ & $(7.5)$ \\
\hline Euro & $\begin{array}{l}-1.41 \\
(1.28)\end{array}$ & $\begin{array}{l}-0.96 \\
(1.56)\end{array}$ & $\begin{array}{l}-0.55 \\
(1.18)\end{array}$ & $\begin{array}{l}-1.21 \\
(1.81)\end{array}$ & $\begin{array}{l}-3.45^{* *} \\
(1.48)\end{array}$ \\
\hline NIIP/Y & $\begin{array}{l}-0.04 * * * \\
(0.01)\end{array}$ & & & & \\
\hline $\mathrm{E}^{*} \mathrm{NIIP} / \mathrm{Y}$ & $\begin{array}{c}0.03 \\
(0.02)\end{array}$ & & & & \\
\hline Net Eq/Y & & $\begin{array}{l}-0.08 * * * \\
(0.02)\end{array}$ & & & \\
\hline $\mathrm{E}^{*}$ Net Eq/Y & & $\begin{array}{c}0.06^{*} \\
(0.04)\end{array}$ & & & \\
\hline Net Dbt/Y & & $\begin{array}{l}-0.02 \\
(0.02)\end{array}$ & & & \\
\hline$E^{*}$ Net Dbt/Y & & $\begin{array}{c}0.00 \\
(0.03)\end{array}$ & & & \\
\hline For Res/Y & & $\begin{array}{l}-0.05 \\
(0.04)\end{array}$ & & & \\
\hline $\mathrm{E}^{*}$ For Res/Y & & $\begin{array}{c}0.03 \\
(0.11)\end{array}$ & & & \\
\hline Net FDI/Y & & & $\begin{array}{l}-0.07 * * * \\
(0.02)\end{array}$ & & \\
\hline $\mathrm{E}^{*} \mathrm{NFDI} / \mathrm{Y}$ & & & $\begin{array}{l}0.06^{* *} \\
(0.03)\end{array}$ & & \\
\hline Net Prt/Y & & & $\begin{array}{l}-0.05 \\
(0.03)\end{array}$ & & \\
\hline$E^{*}$ Net Prt/Y & & & $\begin{array}{c}0.05 \\
(0.05)\end{array}$ & & \\
\hline FDI Ast/Y & & & & $\begin{array}{l}-0.08^{* * *} \\
(0.03)\end{array}$ & \\
\hline E*FDI Ast/Y & & & & $\begin{array}{c}0.06^{*} \\
(0.03)\end{array}$ & \\
\hline FDI Lbt/Y & & & & $\begin{array}{l}0.06^{* *} \\
(0.03)\end{array}$ & \\
\hline $\mathrm{E}^{*} \mathrm{FDI}$ Lbt $/ \mathrm{Y}$ & & & & $\begin{array}{l}-0.06^{*} \\
(0.03)\end{array}$ & \\
\hline Prt Ast/Y & & & & & $\begin{array}{l}-0.06 \\
(0.05)\end{array}$ \\
\hline E*Prt Ast/Y & & & & & $\begin{array}{c}0.05 \\
(0.07)\end{array}$ \\
\hline Prt Lbt/Y & & & & & $\begin{array}{c}0.02 \\
(0.03)\end{array}$ \\
\hline$E^{*} \operatorname{Prt} \operatorname{Lbt} / Y$ & & & & & $\begin{array}{l}-0.01 \\
(0.06)\end{array}$ \\
\hline Constant & $\begin{array}{l}25.57 * * * \\
(6.99) \\
\end{array}$ & $\begin{array}{l}19.54 * * \\
(7.47) \\
\end{array}$ & $\begin{array}{l}19.29 * * \\
(7.57) \\
\end{array}$ & $\begin{array}{l}21.89 * * * \\
(7.59)\end{array}$ & $\begin{array}{l}22.14 * * \\
(8.66)\end{array}$ \\
\hline $\begin{array}{l}\text { Adjusted } \mathrm{R}^{2} \\
\mathrm{~N}\end{array}$ & $\begin{array}{r}0.49 \\
67\end{array}$ & $\begin{array}{r}0.50 \\
67\end{array}$ & $\begin{array}{r}0.50 \\
67\end{array}$ & $\begin{array}{r}0.49 \\
67\end{array}$ & $\begin{array}{r}0.42 \\
67\end{array}$ \\
\hline
\end{tabular}

Note: See text for variable definitions. $* * *, * * *$ denote $10 \%, 5 \%$ and $1 \%$ levels of significance 
Table 8

Average GDP Growth (2008-09) and External Assets and Liabilities:

Balance Sheet Ratios

\begin{tabular}{|c|c|c|c|c|c|c|}
\hline & $(8.1)$ & $(8.2)$ & $(8.3)$ & $(8.4)$ & $(8.5)$ & $(8.6)$ \\
\hline \multirow[t]{2}{*}{ Cur Act/Y } & $0.22 * * *$ & $0.27 * * *$ & $0.20 * * *$ & $0.19 * *$ & $0.20 * * *$ & $0.22 * * *$ \\
\hline & $(0.07)$ & $(0.07)$ & $(0.07)$ & $(0.08)$ & $(0.07)$ & $(0.07)$ \\
\hline \multirow[t]{2}{*}{$\Delta \mathrm{Dom} \mathrm{Cr} / \mathrm{Y}$} & $-0.04^{*}$ & $-0.04^{*}$ & $-0.05^{* *}$ & $-0.05^{*}$ & $-0.06^{* *}$ & $-0.05^{*}$ \\
\hline & $(0.02)$ & $(0.03)$ & $(0.03)$ & $(0.03)$ & $(0.03)$ & $(0.03)$ \\
\hline \multirow[t]{2}{*}{ Trad Open/Y } & -0.02 & -0.02 & -0.01 & -0.01 & -0.01 & -0.01 \\
\hline & $(0.01)$ & $(0.01)$ & $(0.01)$ & $(0.01)$ & $(0.01)$ & $(0.01)$ \\
\hline \multirow[t]{2}{*}{ Fin Open/Y } & 0.00 & 0.00 & -0.00 & -0.00 & -0.00 & -0.00 \\
\hline & $(0.00)$ & $(0.00)$ & $(0.00)$ & $(0.00)$ & $(0.00)$ & $(0.00)$ \\
\hline \multirow[t]{2}{*}{$\mathrm{NIIP} / \mathrm{Y}$} & $-0.04 * * *$ & $-0.04 * * *$ & $-0.03 * *$ & $-0.03 * *$ & $-0.04 * * *$ & $-0.04 * *$ \\
\hline & $(0.01)$ & $(0.01)$ & $(0.01)$ & $(0.01)$ & $(0.01)$ & $(0.01)$ \\
\hline Eq Ast/Ast & $\begin{array}{l}-0.09^{* * * *} \\
(0.02)\end{array}$ & & & & & \\
\hline $\mathrm{Eq} \mathrm{Lbt/Lbt}$ & $\begin{array}{l}0.08 * * * \\
(0.03)\end{array}$ & & & & & \\
\hline FDI Ast/Ast & & $\begin{array}{l}-0.10 * * * \\
(0.04)\end{array}$ & & & & \\
\hline FDI Lbt/Lbt & & $\begin{array}{c}0.06^{*} \\
(0.03)\end{array}$ & & & & \\
\hline Prt Ast/Ast & & & $\begin{array}{l}-0.10^{* *} \\
(0.05)\end{array}$ & & & \\
\hline Prt Lbt/Lbt & & & $\begin{array}{c}0.02 \\
(0.04)\end{array}$ & & & \\
\hline Dbt Ast/Ast & & & & $\begin{array}{c}0.03 \\
(0.03)\end{array}$ & & \\
\hline Dbt Lbt/Lbt & & & & $\begin{array}{l}-0.07 \\
(0.04)\end{array}$ & & \\
\hline Eq Ast/Dbt Ast & & & & & $\begin{array}{l}-0.01 * * \\
(0.01)\end{array}$ & \\
\hline $\mathrm{Eq} \mathrm{Lbt/Dbt} \mathrm{Lbt}$ & & & & & $\begin{array}{l}0.02 * * \\
(0.01)\end{array}$ & \\
\hline FDI Ast/Dbt Ast & & & & & & $\begin{array}{l}-0.01 \\
(0.01)\end{array}$ \\
\hline FDI Lbt/Dbt Lbt & & & & & & $\begin{array}{r}0.02^{*} \\
(0.01)\end{array}$ \\
\hline Constant & $\begin{array}{l}-0.11 \\
(1.74)\end{array}$ & $\begin{array}{c}1.28 \\
(1.50) \\
\end{array}$ & $\begin{array}{r}2.70^{*} \\
(1.39)\end{array}$ & $\begin{array}{c}4.35 * * \\
(2.03)\end{array}$ & $\begin{array}{c}0.86 \\
(1.38)\end{array}$ & $\begin{array}{c}1.15 \\
(1.36)\end{array}$ \\
\hline Adjusted $\mathrm{R}^{2}$ & 0.37 & 0.31 & 0.25 & 0.22 & 0.28 & 0.24 \\
\hline $\mathrm{N}$ & 67 & 67 & 67 & 67 & 67 & 67 \\
\hline
\end{tabular}

Note: See text for variable definitions. $* * *, * * *$ denote $10 \%, 5 \%$ and $1 \%$ levels of significance 


\section{References}

Ahrend, Rudiger and Antoine Goujard. 2014. "Drivers of Systemic Banking Crises: The Role of Financial Account Structure and Financial Integration.” International Finance 17 (2): 135-160.

Aizenman, Joshua and Yi Sun. 2012. "The Financial Crisis and Sizable International Reserves Depletion: From 'Fear of Floating' to the 'Fear of Losing International Reserves." International Review of Economics and Business 24 (1): 250-269.

Alfaro, Laura and Maggie Xiaoyang Chen. 2012. "Surviving the Global Financial Crisis: Foreign Ownership and Establishment Performance." American Economic Journal: Economic Policy 4 (3): $30-55$.

Al-Saffar, Yaser, Wolfgang Ridinger and Simon Whitaker. 2013. "The Role of External Balance Sheets in the Financial Crisis." Bank of England Financial Stability Paper no. 24. London: Bank of England.

Balli, Faruk, Syed Abul Basher and Hatice Ozer Balli. 2011. "Income Insurance and the Determinants of Income Insurance via Foreign Asset Revenues and Foreign Liability Payments." Economic Modelling 28 (5): 2296-2306.

Balli, Faruk, Syed Abul Basher and Hatice Ozer Balli. 2013. "International Income Risk-Sharing and the Global Financial Crisis of 2008-2009." Journal of Banking and Finance 37 (7): 23032313.

Berkmen, S. Pelin, Gaston Gelos, Robert Rennhack and James P. Walsh. 2012. "The Global Financial Crisis: Explaining Cross-Country Differences in the Output Impact." Journal of International Money and Finance 31 (1): 42-59.

Bracke, Thierry and Martin Schmitz. 2011. "Channels of International Risk-Sharing: Capital Gains versus Income Flows." International Economics and Economic Policy 8 (1): 45-78.

Bussiére, Matthieu, Gong Cheng, Menzie D. Chinn and Noëmie Lisack. 2015. "For a Few Dollars More: Reserves and Growth in Times of Crises." Journal of International Money and Finance 52: 127-145.

Campion, Mary Kathryn and Rebecca M. Neumann. 2003. "Compositional Effects of Capital Controls - Theory and Evidence." World Economy 26 (7): 957-973.

Campion, Mary Kathryn and Rebecca M. Neumann. 2004. "Compositional Effects of Capital Controls: Evidence from Latin America." North American Journal of Economics and Finance 15 (2): 161-178.

Catão, Luis A. V. and Gian Maria Milesi-Ferretti. 2014. "External Liabilities and Crises." Journal of International Economics 94 (1): 18-32. 
Cavallo, Michele, Kate Kisselev, Fabrizio Perri and Nouriel Roubini. 2005. "Exchange Rate Overshooting and the Costs of Floating." Federal Reserve Bank of San Francisco Working Paper no. 2005-07. San Francisco: Federal Reserve Bank of San Francisco.

Ceballos, Francisco, Tatiana Didier, Constantino Hevia and Sergio Schmukler. 2013. "Policy Responses to the Global Financial Crisis: What Did Emerging Economies Do Differently?" Banco Central de Reserve del Perú Working Paper no. 2013-002. Lima, Perú: Banco Central de Reserve del Perú.

Chui, Michael, Ingo Fender and Vladyslav Sushko. 2014. "Risks Related to EME Corporate Balance Sheets: The Role of Leverage and Currency Mismatch." BIS Quarterly Review, September, p. 35-47.

Daude, Christian and Marcel Fratzscher. 2008. "The Pecking Order of Cross-Border Investment." Journal of International Economics 74 (1): 94-119.

Devereux, Michael B. and Alan Sutherland. 2009. "A Portfolio Model of Capital Flows to Emerging Markets.” Journal of Development Economics 89 (2): 181-193.

Didier, Tatiana, Constantino Hevia and Sergio L. Schmukler. 2012. "How Resilient and Countercyclical Were Emerging Economies During the Global Financial Crisis?" Journal of International Money and Finance 31 (8): 2052-2077.

Dominguez, Kathryn M. E., Yuko Hashimoto and Takatoshi Ito. 2012. "International Reserves and the Global Financial Crisis." Journal of International Economics 88 (2): 388-406.

Eichengreen, Barry and Ricardo Hausmann (eds.). 2005. Other People's Money: Debt Denomination and Financial Instability in Emerging Market Economies. Chicago: University of Chicago Press.

Faria, André and Paolo Mauro. 2009. "Institutions and the External Capital Structure of Countries.” Journal of International Money and Finance 28 (3): 367-391.

Faria, André, Philip R. Lane, Paolo Mauro and Gian Maria Milesi-Ferretti. 2007. "The Shifting Composition of External Liabilities." Journal of the European Economic Association 5 (2-3): 480-490.

Frankel, Jeffrey and George Saravelos. 2012. "Can Leading Indicators Assess Country Vulnerability? Evidence from the 2008-09 Global Financial Crisis." Journal of International Economics 87 (2): 216-231.

Frankel, Jeffrey and Shang-Jin Wei. 2005). "Managing Macroeconomic Crises: Policy Lessons." In Joshua Aizenman and Brian Pinto (eds.), Managing Economic Volatility and Crises: A Practitioner's Guide. Cambridge, UK" Cambridge University Press, p. p. 315-405. 
Forbes, Kristin J. and Francis E. Warnock. 2012. "Debt- and Equity-Led Capital Flow Episodes." NBER Working Paper no. 18329. Cambridge, MA: National Bureau of Economic Research.

Furceri, David, Stéphanie Guichard and Elena Rusticelli. 2012. "Episodes of Large Capital Inflows, Banking and Currency Crises, and Sudden Stops." International Finance 15 (1): 1 - 35.

Globan, Tomislav. 2012. "Capital Flow Reversals during a Financial Crises: Does the Pre-crisis Composition Matter?” Ekonomski Pregled 63 (1): 587-607.

Gourinchas, Pierre-Olivier and Hélène Rey. 2007a. "From World Banker to World Venture Capitalist: U.S. External Adjustment and the Exorbitant Privilege." In Richard H. Clarida (ed.), G7 Current Account Imbalances: Sustainability and Adjustment. Chicago: University of Chicago Press, p. 11-66.

Gourinchas, Pierre-Olivier and Hélène Rey. 2007b. "International Financial Adjustment." Journal of Political Economy 115 (4): 665-703.

Gourinchas, Pierre-Olivier and Hélène Rey. 2014. "External Adjustment, Global Imbalances, Valuation Effects." In Gita Gopinath, Elhanan Helpman and Kenneth Rogoff (eds.) Handbook of International Economics Volume 4. Amsterdam: Elsevier, p. 585-645.

Gourinchas, Pierre-Olivier, Hélène Rey and Nicolas Govillot. 2010. "Exorbitant Privilege and Exorbitant Duty.” Manuscript.

Gourinchas, Pierre-Olivier, Hélène Rey and Kai Truempler. 2012. "The Financial Crisis and the Geography of Wealth Transfer.” Journal of International Economics 88 (2): 266-283.

Habib, Maurizio Michael. 2010. "Excess Returns on Net Foreign Assets: The Exorbitant Privilege From a Global Perspective.” ECB Working Paper Series no. 1158. Frankfurt: European Central Bank.

Hale, Galina B., Peter Jones and Mark M. Spiegel. 2014. "The Rise in Home Currency Issuance." Federal Reserve Bank of San Francisco Working Paper \#2014-19. San Francisco: Federal Reserve Bank of San Francisco.

He, Dong, Lillian Cheung, Wenlang Zhang and Tommy Wu. 2012. "How Would Capital Account Liberalisation Affect China's Capital Flow and the Renminbi Real Exchange Rates?" HKIMR Working Paper no. 09/2012. Hong Kong: Hong Kong Institute for Monetary Research.

Hutchison, Michael M. and Ilan Noy. 2002. "Output Costs of Currency and Balance of Payments Crises in Emerging Markets.” Comparative Economic Studies 44 (2): 27-44.

International Monetary Fund. 2012. World Economic Outlook. October. Washington, DC: International Monetary Fund. 
Joyce, Joseph P. 2011. "Financial Globalization and Banking Crises in Emerging Markets." Open Economies Review 22 (5): 875-895.

Joyce, Joseph P. 2012. The IMF and Global Financial Crises: Phoenix Rising? Cambridge, UK and New York: Cambridge University Press.

Kauko, Karlo. 2014. "How to Foresee Banking Crises? A Survey of the Empirical Literature." Economic Systems 38 (3): 289-308.

Klein, Michael W. 2012. "Capital Controls: Gates versus Walls." Brookings Papers on Economic Activity. Fall: 317-355.

Kose, M. Ayhan and Eswar S. Prasad. 2010. Emerging Markets: Resilience and Growth Amid Global Turmoil. Washington, DC: Brookings Institution Press.

Kubelec, Chris, Bjorn-Erik Orskaug and Misa Tanaka. 2007. "Financial Globalisation, External Balance Sheets and Economic Adjustment." Bank of England Quarterly Bulletin 47 (2): 244257.

Laeven, Luc and Fabian Valencia. 2013. "Systemic Banking Crises Database." IMF Economic Review 61 (2): 225-270.

Lane, Philip R. 2001. "Do International Investment Income Flows Smooth Income?" Welwirtschaftliches Archiv 137 (4): 714-736.

Lane, Philip R. 2013. "Financial Globalisation and the Crisis." Open Economies Review 24 (3): 555-580.

Lane, Philip R. and Gian Maria Milesi-Ferretti. 2001. "The External Wealth of Nations: Measures of Foreign Assets for Industrial and Developing Countries." Journal of International Economics 55 (2): 263-294.

Lane, Philip R. and Gian Maria Milesi-Ferretti. 2007. "The External Wealth of Nations II: Extended Estimates of Foreign Assets and Liabilities, 1970-2004." Journal of International Economics 73 (2): 223-250.

Lane, Philip R. and Gian Maria Milesi-Ferretti. 2011. "The Cross-Country Incidence of the Global Crisis." IMF Economic Review 59 (1): 77-110.

Lane, Philip R. and Sergio L. Schmukler. 2007. "The Evolving Role of China and India in the Global Financial System.” Open Economies Review 18 (4): 499-520.

Levchenko, Andrei A. and Paolo Mauro. 2007. "Do Some Forms of Financial Flows Help Protect Against 'Sudden Stops'?” The World Bank Economic Review 21 (3): 389-411. 
Lipsey, Robert E. 2001. "Foreign Direct Investors in Three Financial Crises." NBER Working Paper no. 8084. Cambridge, MA: National Bureau of Economic Research.

Llaudes, Ricardi, Ferhan Salman and Mali Chivakul. 2010. "The Impact of the Great Recession on Emerging Markets." IMF Working Paper no. 10/237. Washington, DC: International Monetary Fund.

Ma, Guonan and Robert N. McCauley. 2014. "Global and Euro Imbalances: China and Germany." China \& World Economy 22 (2): 1-29.

Mendoza, Enrique G., Vincenzo Quadrini, and José-Victor Ríos-Rull. 2009. "Financial Integration, Financial Development and Global Imbalances. " Journal of Political Economy 117 (31): 371-416.

Mendoza, Enrique G. and Katherine A. Smith. 2014. "Financial Globalization, Financial Crises, and the External Portfolio Structure of Emerging Markets." Scandinavian Journal of Economics 116 (1): 20-57.

Montiel, Peter and Carmen M. Reinhart. 1999. "Do Capital Controls and Macroeconomic Policies Influence the Volume and Composition of Capital Flows? Evidence from the 1990s." Journal of International Money and Finance 18 (4): 619-635.

Myers, Stewart C. and Nicholas S. Majluf. 1984. "Corporate Financing and Investment Decisions When Firms Have Information That Investors Do Not Have." Journal of Financial Economics 13 (2): 187-221.

Ostry, Jonathan D., Atish R. Ghosh, Karl Habermeier, Marcos Chamo, Mahvash S. Qureshi and Dennis B. S. Reinhardt. 2010. Capital Inflows: The Role of Controls. IMF Staff Position Note no. 10/04. Washington, DC: International Monetary Fund.

Pistelli, Alfredo, Jorge Selaive and Rodrigo O. Valdés. 2008. "Stocks, Flows, and Valuation Effects of Foreign Assets and Liabilities: Do They Matter?" In Sebastián Edwards and Rodrigo O. Valdés (eds.), Current Account and External Financing. Santiago, Chile: Central Bank of Chile, p. 237-277.

Razin, Assaf, Efraim Sadka and Chi-Wa Yuen. 1998. "A Pecking Order of Capital Inflows and International Tax Principles." Journal of International Economy 44 (1): 45-68.

Reinhart, Carmen and Ken Rogoff. 2004. "The Modern History of Exchange Rate Arrangements: A Reinterpretation." Quarterly Journal of Economics 119 (1): 1-48.

Reisen, Helmut and Marcelo Soto. 2001. "Which Types of Capital Inflows Foster DevelopingCountry Growth?" International Finance 4 (1): 1-14. 
Rodrik, Dani and André Velasco. 2000. "Short-Term Capital Flows." In Boris Plesovic and Joseph E. Stiglitz (eds.) Annual World Bank Conference on Development Economics 1999. Washington, DC: International Bank for Reconstruction and Development, p. 59-90.

Schmitz, Martin. 2010. "Financial Markets and International Risk-Sharing." Open Economies Review 21 (3): 413-431.

Schmitz, Martin. 2013. "Financial Markets and International Risk Sharing in Emerging Market Economies." International Journal of Finance \& Economics 18 (3): 266-277.

Sturm, Jan-Egbert, Helge Berger and Jakob de Haan. 2005. "Which Variables Explain Decisions on IMF Credit? An Extreme Bounds Analysis." Economics and Politics 17 (2): 177-213.

Sula, Ozan and Thomas D. Willett. 2009. "The Reversibility of Different Types of Capital Flows to Emerging Markets.” Emerging Markets Review 10 (4): 296-310.

Tong, Hui and Shang-Jin Wei. 2010. "The Composition Matters: Capital Inflows and Liquidity Crunch During a Global Economic Crisis." Review of Financial Studies 24 (6): 2023-2052.

Vermeulen, Robert and Jakob de Haan. 2014. "Net Foreign Asset (Com)position: Does Financial Development Matter?" Journal of International Money and Finance 43 (1): 88-106.

Wei, Shang-Jin. 2011. "Not All Financial Integration is Created Equal: The Composition Matters." In Michael Devereux, Philip R. Lane, Cyn-Young Park and Shang-Jin Wei (eds.), The Dynamics of Asian Financial Integration: Facts and Analytics. London and New York: Routledge, p. 259-283. 
Appendix

Table A1

List of Countries

\begin{tabular}{|c|c|c|}
\hline \multicolumn{3}{|c|}{ Advanced Economies } \\
\hline Australia & Greece $^{+}$ & Slovenia $^{+}$ \\
\hline Austria $^{+}$ & Israel & South Korea \\
\hline Belgium $^{+}$ & Italy $^{+}$ & Spain $^{+}$ \\
\hline Canada & Japan & Sweden $^{+}$ \\
\hline Denmark $^{+}$ & Netherlands $^{+}$ & Switzerland $^{+}$ \\
\hline Finland & New Zealand & United Kingdom $^{+}$ \\
\hline France $^{+}$ & Norway & United States $^{+}$ \\
\hline Germany $^{+}$ & Portugal $^{+}$ & \\
\hline \multicolumn{3}{|c|}{ Emerging Economies } \\
\hline Algeria & Estonia & Peru \\
\hline Azerbaijan & Guatemala* & Philippines \\
\hline Belarus* & Hungary $^{+}, *$ & Poland \\
\hline Brazil & India & Romania* \\
\hline Bulgaria & Indonesia & Russia $^{+}$ \\
\hline Chile & Jordan & Slovak Republic \\
\hline China & Kazakhstan $^{+}$ & South Africa \\
\hline Colombia & Latvia $^{+}, *$ & Sri Lanka* \\
\hline Costa Rica* & Lebanon & Thailand \\
\hline Croatia & Lithuania & Tunisia \\
\hline Czech Republic & Malaysia & Turkey \\
\hline Dominican Republic* & Mexico & Ukraine $^{+}, *$ \\
\hline Ecuador & Morocco & Uruguay \\
\hline Egypt & Pakistan* & Venezuela \\
\hline El Salvador* & Panama & \\
\hline
\end{tabular}

Note: ${ }^{+}$Bank crisis 2008-09, *IMF program 2008-09 
Table A2

Data Sources

\begin{tabular}{|c|c|c|}
\hline Symbol & Definition & Source \\
\hline Cur Acct/Y & Current Account/GDP (\%) & EWN \\
\hline $\begin{array}{l}\text { Dbt Ast/Ast, Dbt Ast/Y } \\
\text { Dbt Lbt/Lbt, Dbt Lbt/Y }\end{array}$ & $\begin{array}{l}\text { Debt Assets/Assets, Debt Assets/GDP, } \\
\text { Debt Liabilities/Liabilities, Debt } \\
\text { Liabilities/GDP (\%) }\end{array}$ & EWN \\
\hline$\Delta \mathrm{Dm} \mathrm{Cr} / \mathrm{Y}$ & $\begin{array}{l}\text { Change in Domestic Credit to Private } \\
\text { Sector/GDP, 2004-2007 (\%) }\end{array}$ & $W D I$ \\
\hline $\begin{array}{l}\text { Eq Ast/Ast, } \\
\text { Eq Ast/Dbt Ast, } \\
\text { Eq Lbt/Lbt, } \\
\text { Eq Lbt/Dbt Lbt }\end{array}$ & $\begin{array}{l}\text { Equity Assets/Assets, Equity Assets/Debt } \\
\text { Assets, Equity Liabilities/Liabilities, } \\
\text { Equity Liabilities/Debt Liabilities (\%) }\end{array}$ & EWN \\
\hline $\begin{array}{l}\text { FDI Ast/Ast, FDI Ast/Y } \\
\text { FDI Lbt/Lbt, FDI Lbt/Y }\end{array}$ & $\begin{array}{l}\text { FDI Assets/Assets, FDI Assets/GDP, } \\
\text { FDI Liabilities/Liabilities, FDI Liabilities/Y } \\
(\%)\end{array}$ & EWN \\
\hline $\begin{array}{l}\text { FDI Ast/Dbt Ast, } \\
\text { FDI Lbt/Dbt Lbt }\end{array}$ & $\begin{array}{l}\text { FDI Assets/Debt Assets, } \\
\text { FDI Liabilities/Debt Liabilities (\%) }\end{array}$ & EWN \\
\hline Fin Open/Y & External Assets + Liabilities/GDP (\%) & EWN \\
\hline Fix & $\begin{array}{l}\text { Fixed Exchange Rate Regime }=1 \\
\text { if Reinhart and Rogoff }=1-8\end{array}$ & $\begin{array}{l}\text { Reinhart and } \\
\text { Rogoff (2004) }\end{array}$ \\
\hline $\begin{array}{l}\text { For Res/Y, } \\
\text { For Res/Imp }\end{array}$ & $\begin{array}{l}\text { Foreign Reserves/Y, } \\
\text { Foreign Reserves/Imports (\%) }\end{array}$ & $\begin{array}{l}\text { EWN, } \\
W D I\end{array}$ \\
\hline Gov/Y & Government Consumption/GDP (\%) & $W D I$ \\
\hline $\begin{array}{l}\text { Net Dbt/Y, Net Eq/Y, } \\
\text { Net FDI/Y, Net Prt/Y }\end{array}$ & $\begin{array}{l}\text { Net Debt/GDP, Net Equity/GDP, Net } \\
\text { FDI/GDP, Net Portfolio Equity/GDP (\%) }\end{array}$ & EWN \\
\hline NIIP/Y & Net International Investment Position/GDP (\%) & EWN \\
\hline$\% \Delta \mathrm{P}$ & Growth Rate of Consumer Price Index (\%) & $W D I$ \\
\hline
\end{tabular}


Table A2 (continued)

Data Sources

\begin{tabular}{lll}
\hline Symbol & Definition & Source \\
\hline Prt Ast/Ast, Prt Ast/Y, & Portfolio Equity Assets/Assets, Portfolio Equity & EWN \\
Prt Lbt/Lbt, Prt Lbt/Y & $\begin{array}{l}\text { Assets/GDP, Portfolio Equity Liabilities/ } \\
\text { Liabilities, Portfolio Liabilities/GDP (\%) }\end{array}$ & \\
Trad Open/Y & Exports + Imports/GDP (\%) & WDI \\
$\% \Delta \mathrm{Y}$ & Growth Rate of Real GDP (\%) & WDI \\
Y/Pop & $\begin{array}{l}\text { Logarithm of GDP Per-capita (2011 } \\
\text { international \$) }\end{array}$ & WDI \\
\hline
\end{tabular}

Note: EWN = "External Wealth of Nations", WDI = World Development Indicators 
Table A3

Descriptive Statistics: External Balance Variables

\begin{tabular}{l|rrrc}
\hline \multicolumn{1}{c}{ Variable } & Mean & Minimum & Maximum & Std Dev \\
\hline Dbt Ast/Ast & 46.02 & 4.83 & 91.68 & 10.05 \\
Dbt Ast/Y & 61.75 & 1.37 & 403.70 & 80.082 \\
Dbt Lbt/Lbt & 51.79 & 22.13 & 76.01 & 14.38 \\
Dbt Lbt/Y & 82.88 & 4.51 & 370.49 & 77.59 \\
Eq Ast/Ast & 24.44 & 0.28 & 76.21 & 19.02 \\
Eq Ast/Dbt Ast & 73.57 & 0.31 & 349.74 & 82.63 \\
Eq Lbt/Dbt Lbt & 108.55 & 10.75 & 351.81 & 71.75 \\
Eq Lbt/Lbt & 46.64 & 6.76 & 77.87 & 15.75 \\
FDI Ast/Ast & 15.05 & 0.00 & 63.29 & 12.40 \\
FDI Ast/Dbt Ast & 46.69 & 0.00 & 305.63 & 61.18 \\
FDI Ast/Y & 22.83 & 0.00 & 145.23 & 32.77 \\
FDI Lbt/Lbt & 34.02 & 3.05 & 170.46 & 15.43 \\
FDI Lbt/Dbt Lbt & 77.55 & 7.64 & 200.18 & 52.13 \\
FDI Lbt/Y & 43.58 & 3.05 & 170.46 & 31.06 \\
Fin Open/Y & 270.07 & 54.92 & 1252.77 & 249.74 \\
For Res/Y & 16.22 & 0.21 & 81.61 & 14.81 \\
Net Debt/Y & -21.13 & -107.87 & 111.31 & 30.53 \\
Net Eq/Y & -24.86 & -146.82 & 35.07 & 30.93 \\
Net FDI/Y & -20.75 & -109.01 & 60.58 & 27.91 \\
Net Prt/Y & -4.59 & -47.58 & 52.32 & 16.43 \\
NIIP/Y & -30.14 & -136.87 & 146.59 & 47.16 \\
Prt Ast/Ast & 9.39 & 0.00 & 39.01 & 10.10 \\
Prt Ast/Y & 15.58 & 0.00 & 113.49 & 23.46 \\
Prt Lbt/Lbt & 13.07 & 0.00 & 52.50 & 12.59 \\
Prt Lbt/Y & 20.17 & 0.00 & 161.06 & 25.76 \\
\hline
\end{tabular}

Table A4

Descriptive Statistics: Control Variables

\begin{tabular}{l|rccc}
\hline \multicolumn{1}{c|}{ Variable } & Mean & Minimum & Maximum & Std Dev \\
\hline Cur Acc/Y & -1.67 & -27.12 & 27.26 & 9.18 \\
$\Delta$ Dm Cred/Y & 11.41 & -77.28 & 61.14 & 18.78 \\
Gov/Y & 15.71 & 7.62 & 24.33 & 4.47 \\
$\% \Delta \mathrm{P}$ & 4.73 & 0.06 & 16.60 & 3.56 \\
Trad Open/Y & 84.93 & 25.21 & 192.47 & 36.71 \\
$\% \Delta \mathrm{Y}$ & 5.94 & 0.11 & 25.05 & 3.63 \\
Y/Pop & 9.80 & 8.26 & 11.08 & 0.69 \\
\hline
\end{tabular}

